\title{
O USO DA COMUNICAÇÃO VISUAL NA GEOGRAFIA: A ILUSTRAÇÃO NOS AMBIENTES ESCOLAR, ACADÊMICO E PROFISSIONAL
}

\author{
Sérgio Ricardo Fiori \\ Universidade Federal Rural do Rio de Janeiro - UFRRJ \\ Programa de Pós-Graduação em Geografia \\ srfiori@gmail.com \\ Rodolpho Willian Alves de Lucena \\ Universidade Federal Rural do Rio de Janeiro - UFRRJ \\ rwalucena@hotmail.com
}

\begin{abstract}
RESUMO
A sociedade contemporânea, mais do que em qualquer outro momento histórico, utiliza exponencialmente as mais variadas imagens como meio de comunicação. $O$ artigo se propõe a discutir a ilustração didático-científica - em desenhos, perfis, blocos diagramas e esquemas - como formas de expressão visual da Geografia, podendo auxiliar o professor durante a ministração de suas aulas e consequente transmissão do conteúdo programático; além de fazer com que o estudante, pesquisador, profissional da área possa utilizar e/ou criar representações gráficas em suas atividades cotidianas. Neste contexto, discorre-se sobre dois universos discursivos com características distintas, porém complementares: a comunicação visual, caracterizada pela imagem não verbal e menor grau de abstração da realidade (uso do desenho icônico, figurativo) e a linguagem verbal (escrita, texto), que juntas se estabelecem como um importante recurso didático no processo de ensinoaprendizagem. No entanto, ressalta-se que o sistema educacional trata a ilustração com desconhecimento, levando assim, o desinteresse pelo tema. Ao final, relatam-se alguns exemplos quanto ao desenvolvimento e uso da ilustração em ambientes com maior ou menor aporte tecnológico, ou seja, desde representações analógicas (feitas a mão) até as digitais (realizadas em softwares).
\end{abstract}

Palavras-chave: Ilustração. Comunicação. Recurso didático. Ensino de Geografia.

\section{THE USE OF VISUAL COMMUNICATION IN GEOGRAPHY: THE ILLUSTRATION IN SCHOOL, ACADEMIC AND PROFESSIONAL ENVIRONMENTS}

\begin{abstract}
Contemporary society, more than in any other historical moment, exponentially uses the most varied images as communication medium. The article proposes to discuss the didacticscientific illustration - in drawings, profiles, blocks diagrams and schemes - as forms of visual expression of Geography, being able to assist the teacher during the teaching of his classes and consequent transmission of program content; besides doing that the student, researcher, professional in the area can use and / or create graphic representations in their daily activities. In this context, there are two discursive universes with distinct but complementary characteristics: visual communication, characterized by nonverbal image and lower degree of abstraction from reality (use of iconic, figurative drawing) and verbal language (writing, text), which together are established as an important didactic resource in the teaching-learning process. However, emphasizes that the educational system treats the illustration with ignorance, which leads disinterest on the subject. In the end, some examples are reported about the development and use of illustration in environments with greater or lesser technological support, that is, since analogical (handmade) until digital (made in software) representations.
\end{abstract}

Keywords: Illustration. Communication. Didactic resource. Geography teaching. 


\section{INTRODUÇÃO}

Nas últimas décadas do século XX e no decorrer do século XXI é observado o uso exponencial das representações gráficas para os mais diferentes fins: jornalismo e entretenimento (cartuns, charges, infográficos, ilustrações de matéria), editorial e educação (ilustrações infantis, infanto-juvenis, adultas), publicidade (layouts, storyboards, outdoors), design gráfico, informação e consumo (embalagens de produtos, manuais de aparelho eletrônico, cartazes explicativos), educação (desenhos ilustrativos concebidos a diferentes áreas acadêmicas), entre outros, que se potencializam em um mundo cada vez mais digital. As conquistas tecnológicas - ondas hertzianas, satélites espaciais, evolução dos chips, fibra ótica, etc. - e o barateamento paulatino de equipamentos, como, por exemplo, desktops, laptops, tablets, smartphones, além de escâneres e impressoras domésticas são fundamentais para se entender o atual estilo de vida calcado no grande uso das imagens.

Observa-se ainda, a inegável proximidade entre quem produz a mensagem-informação e o usuárioreceptor, pois se em outros tempos o leitor de um jornal ou revista, telespectador, consumidor em geral, utilizava as mídias de forma quase passiva, hoje com o advento da internet e a interatividade, o mesmo tem a possibilidade de questionar, influenciar, propor alternativas ao conteúdo que the é oferecido por meio de e-mail e redes sociais como whatsapp, facebook, twitter, entre outras, de maneira muito mais rápida e efetiva.

Ao se expor de forma breve o contexto histórico contemporâneo, pergunta-se: como o professor de geografia pode buscar alternativas que melhorem o estímulo, a atenção dos alunos em relação ao processo de aprendizagem em sala de aula? E como o conteúdo programático pode ficar menos abstrato a partir da utilização efetiva da pictografia associada a linguagem verbal (falada e/ou escrita)? Acredita-se que a ilustração pode ser um dos recursos didáticos oferecidos ao estudante, por ser capaz de trazer uma maior proximidade (por atrair, motivar) e compreensão (por deixar a informação menos abstrata) dos conteúdos propostos pelo docente.

Deste modo, o artigo discute a importância da ilustração enquanto recurso pictórico-visual para a Geografia, ao se estabelecer como um poderoso instrumento de comunicação, podendo auxiliar o professor na ministração de aulas e transmissão do conteúdo programático. E se pode ir além, tanto docentes quanto alunos podem vir a fazer uso e/ou criar ilustrações para seus trabalhos escolares, acadêmicos e profissionais.

Dentre as diversas formas de desenhos ilustrativos, a Geografia faz uso das representações didáticocientíficas, baseadas em desenhos, perfis, blocos diagrama e esquemas (FIORI, 2011) - Figura 1. Contudo, mesmo que o recurso seja utilizado há muito tempo, ainda é pouco discutido, valorizado pela área do ensino-aprendizagem e, por isso, merece uma discussão teórico-aplicada que demonstre alguns exemplos relacionados ao desenvolvimento e uso da ilustração como recurso ao profissional geógrafo e/ou estudante de geografia.

\section{O MUNDO DAS IMAGENS E A COMUNICAÇÃO}

Grosso modo, pode-se definir a imagem como um ato fisiológico, ou seja: surge de um feixe de luz que entra pelo olho e chega até a retina, sendo capaz de se adaptar a graus de iluminação e diferenças de intensidade de radiação da luz a partir dos diferentes pontos do campo visual (KEATES, 1982). Agregam-se a esse ato perceptivo implicações mais profundas envolvendo, por exemplo, valores socioculturais e normas que imprimirão percepções em relação à imagem, tornando-a afetiva, precisa e estabelecida em campo semântico ${ }^{1}$ não-delimitado (COELHO, 1993).

Partindo do princípio que os significados que se dão as imagens resultam em grande parte da experiência e do saber (experiências vividas, formação escolar e acadêmica) que a pessoa e/ou grupo social (identidades) adquire anteriormente, pode-se caracterizar a imagem visual como um sistema simbólico (SAMAIN, 1988).

\footnotetext{
${ }^{1}$ Preocupa-se com problemas relativos ao conteúdo da representação (o que dizer sobre algo). Assim, as regras semânticas se estabelecem muito mais por hábitos de conduta do que por proposições cientificamente provadas. Isso porque, as regras se configuram como modelos ou são aprendidas culturalmente, transmitidas por tradição (CARNEIRO, 2001 e SOUZA, 1992). 
Figura 1 - Tipos de ilustrações didático-científicas.

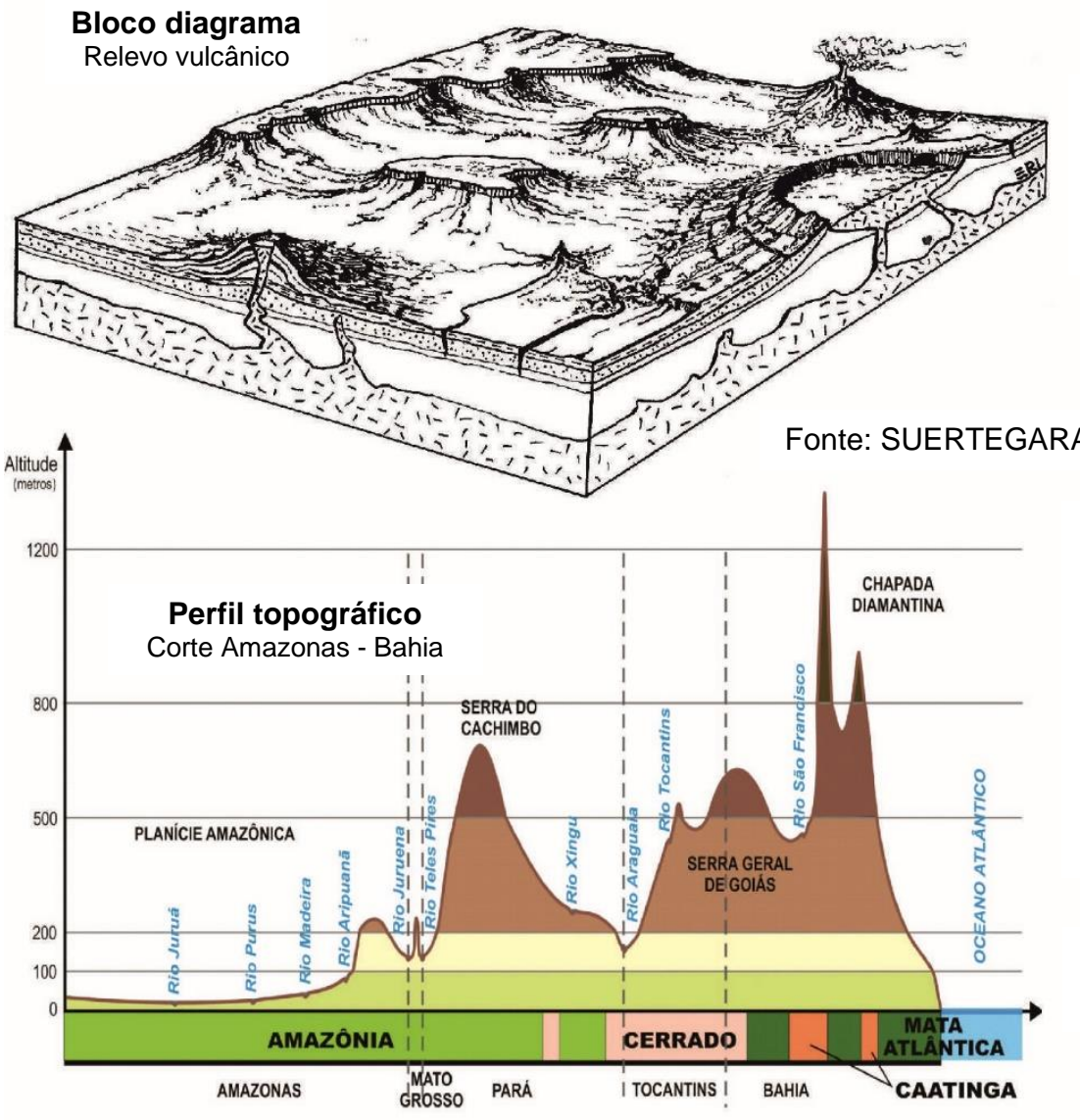

Esquema

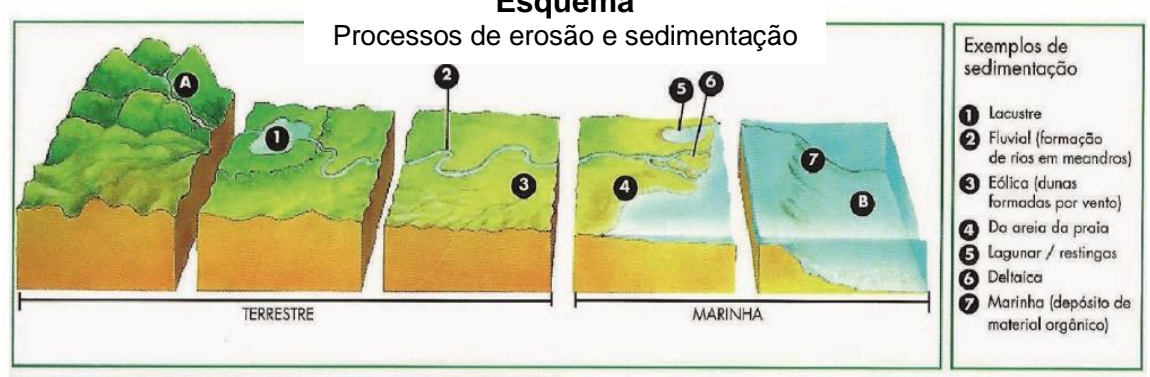

Representa partes da crosta terrestre, onde se observa ao mesmo tempo a topografia e as camadas geológicas.

Representação de um corte do terreno. Todo perfil tem duas escalas: horizontal e vertical. Os perfis topográficos são os mais conhecidos, mas também existem perfis de vegetação, níveis pluviométricos, entre outros.

Ilustração realizada pelo autor.

Descreve os pontos principais de um determinado conteúdo / tema, apresentando, por exemplo, um objeto, elemento ou processo de maneira muito simplificada e funcional.

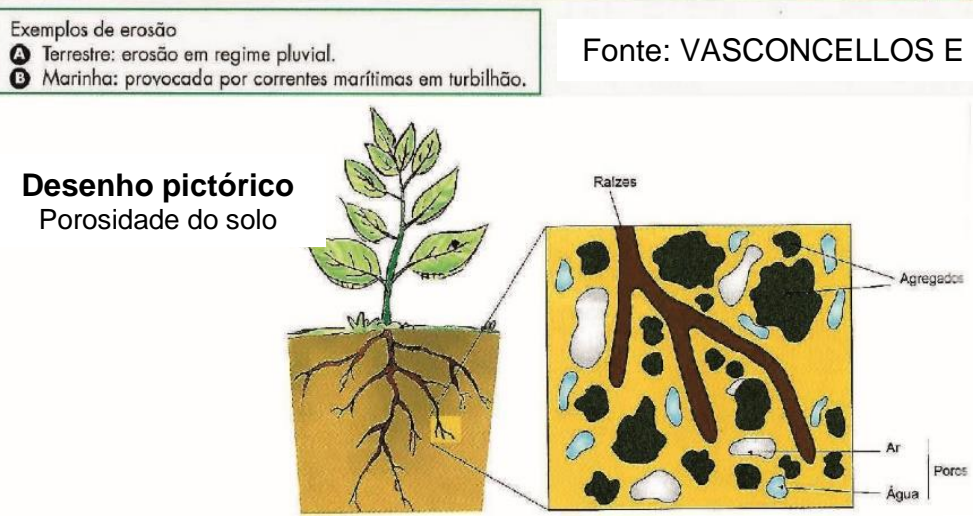

Fonte: OLIVEIRA, 2011, p. 94.

Neste contexto, Rocha-Trindade (1988) afirma que, em algumas disciplinas, a imagem se constitui como apoio esquemático como na geometria, topografia, desenho técnico para a engenharia,

$\begin{array}{lllll}\text { Caminhos de Geografia } \quad \text { Uberlândia-MG } & \text { v. 21, n. } 75 & \text { Jun/2020 } & \text { p.117-136 Página } 119\end{array}$


arquitetura, etc. (Figura 2 A). Já em outros casos, a imagem é um componente mimético da realidade indispensável para a compreensão e a integração do objeto de estudo, citam-se os exemplos da biologia, história da arte, medicina e geografia (Figura 2B).

Figura 2 - Diferentes usos da imagem.

A - Apoio técnico

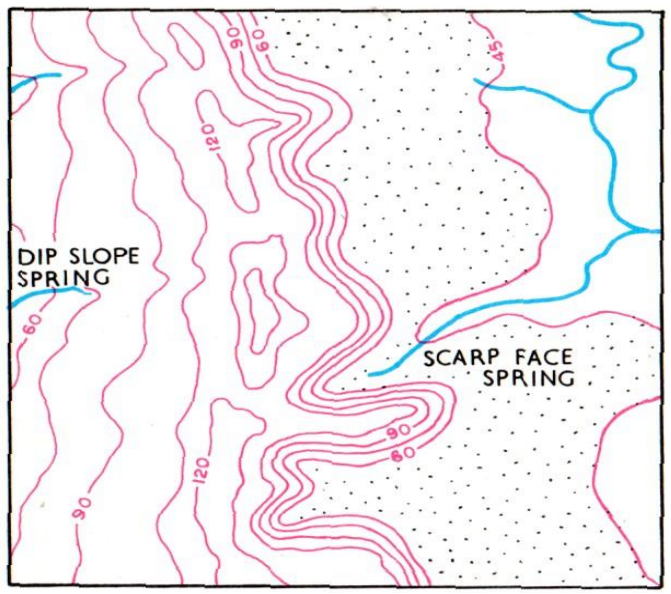

Fonte: MONEY, 1978, p. 38
B - Componente mimético da realidade

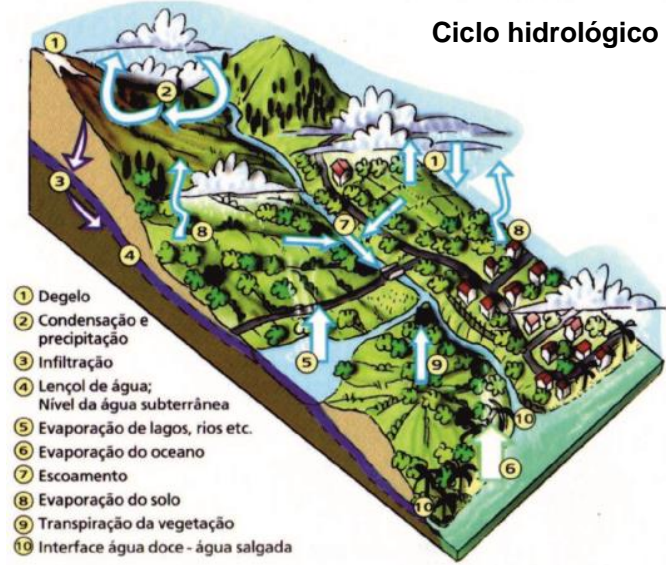

Fonte: FIORI, 2011, p. 399.

Ao se abordar a representação de uma imagem, é fundamental trabalhar o campo da semiótica, que conceitua o signo como um elemento que sempre representa outro: o seu objeto. Em outras palavras, o signo não é o elemento, apenas está em seu lugar, representando-o de certo modo e numa certa capacidade, o qual pode ser interpretado por experiências concretas, sentimentos ou pensamentos. Tudo dependerá da natureza e do potencial do signo, além das condições da vivência de cada pessoa. Coelho Neto (1996), Simões (2007), Peirce (2012), Santaella (2012) e Xavier (2014) revelam a dualidade complementar do signo em (Figura 3):

1) Significante - plano de expressão-percepção do signo caracterizado por sua parte concreta. Relaciona-se as imagens acústicas e visuais provenientes de palavras faladas (fonética) ou escritas (quando se ouve ou se vê uma letra, palavra), ou seja, a palavra traz lembrança de algo a partir de uma imagem sonora e/ou visual de um signo, armazenado no cérebro.

É importante deixar claro, que o plano de expressão-percepção do signo não se atém apenas ao sistema fonético - que representa uma série de sons (letras, consoantes e vogais) para formar as palavras, textos - há também um sistema ideográfico, no qual a palavra é sempre representada por um signo único e arbitrário aos sons. Neste grupo se encontram os desenhos, hieróglifos, símbolos pictóricos, as pinturas rupestres, etc.

Deste modo, quando se ouve ruídos característicos como um som forte e agudo se vem à mente a palavra (escrita ou falada) "buzina"; ao colocar uma concha na orelha pode remeter a palavra "mar"; um objeto de vidro ao cair no chão lembra um "copo", e assim por diante. Já ao se pensar a palavra tendo como referência o sistema ideográfico, o símbolo de uma cruz vermelha faz lembrar de palavras como "hospital, pronto-socorro, saúde"; o desenho de um telhado, com paredes e janela a palavra "casa"; a junção em uma placa com três pictogramas ${ }^{2}$ : mulher, tesoura e pente indica um

${ }^{2}$ Descrevem graficamente objetos, atividades, conceitos por meio de desenhos figurativos, não-verbais, devendo ser diretos, autoexplicativos, isto porque, muitas vezes apresentam alguma semelhança física com o elemento representado, possibilitando assim, uma fácil compreensão da informação. Ex.: o pictograma com um garfo e faca nos remete a restaurante, o pictograma com um elefante nos remete a zoológico, o pictograma com uma cama nos remete a hotel, e assim por diante (FIORI, 2010 e 2014). 
serviço = cabeleireira; e uma fotografia com coqueiros, sol, calor, areia branca e água azul esverdeada nos remete a palavra "praia".

2) Significado - plano do conceito-interpretativo do signo, caracterizado por sua parte abstrata (conceito psíquico) na transmissão do conteúdo, a qual está relacionada a apreensão das coisas por meio da vivência, cultura, experiências (pessoais, sociais), ensino-aprendizagem, etc. Em outras palavras, o significante só terá significado para o receptor quando a mensagem enviada a sua mente (intelecto, memória) faz sentido, lembrança de um som, desenho, objeto, sinal, estabelecendo assim, correspondência de sentido com o significante e compreensão da mensagem.

Figura 3 - A dualidade do signo.

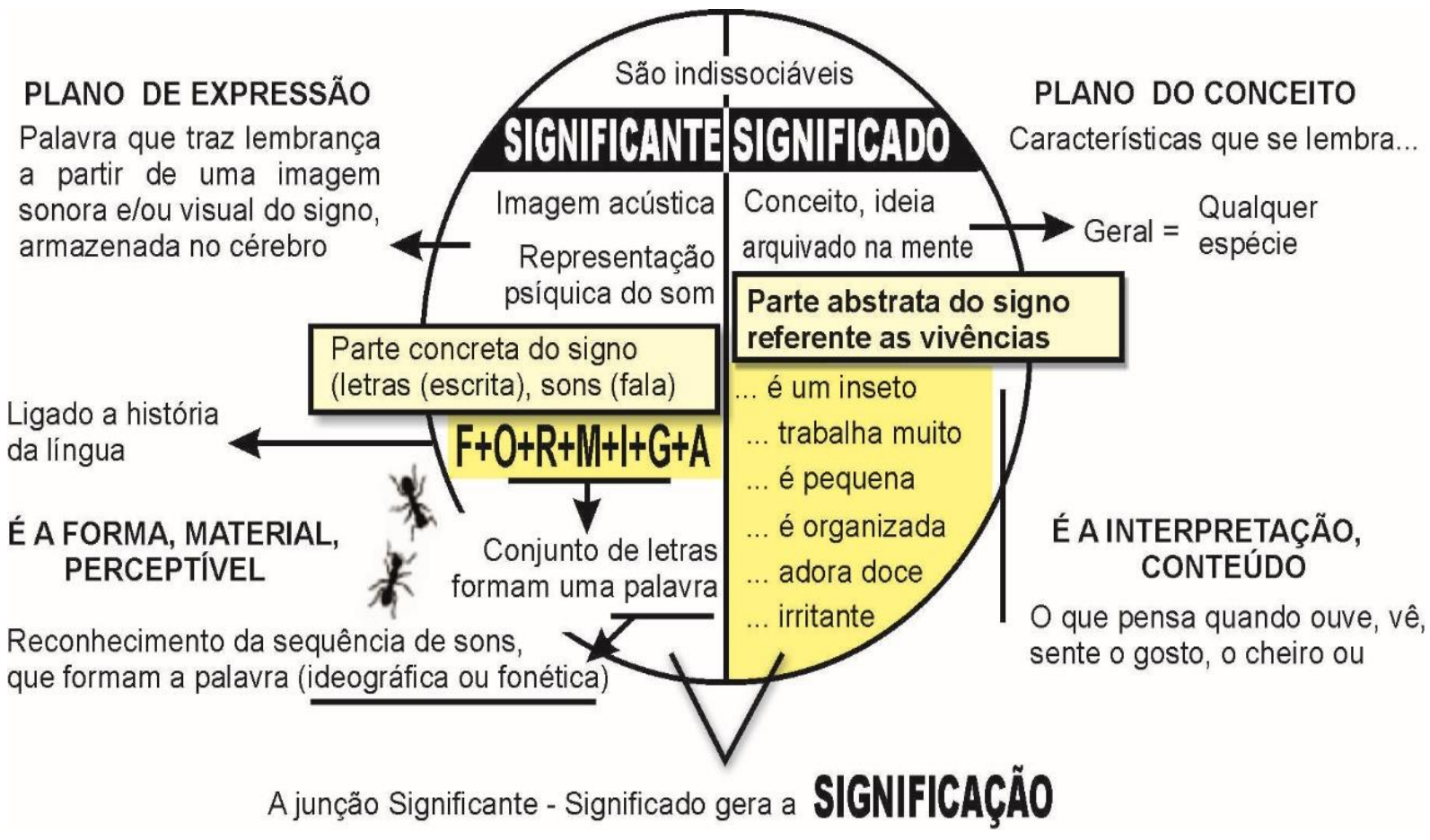

Figura realizada pelo autor baseada em SANTAELLA (2012) e PEIRCE (2012).

Por exemplo: um dos colegas de trabalho em um diálogo na empresa usa a palavra "fastidioso" para falar do chefe, porém o colega que ouve não entende o significado da palavra. No caso, a palavra "fastidioso" possui um significante (palavra falada e ouvida na conversa), mas somente a pessoa que fala entende o significado, isto é, pessoa rabugenta, rígida, severa. Em outro caso, alguém mostra a foto/desenho de um ornitorrinco (mamífero endêmico da Austrália) a duas pessoas, uma delas quando vê a imagem ideográfica (que é o significante) não consegue saber que animal é aquele (não sabe o significado, pois nunca tinha visto falar daquele animal!), enquanto a outra exclama: é um belo ornitorrinco! - demonstrando conhecer o significado; consequentemente, a eficácia da representação está condicionada a vivência, ao aprendizado.

Portanto, ao se ouvir um som característico, ler uma palavra, olhar um desenho, ouvir um latido ou simplesmente ver a imagem de um "cachorro", apresentam-se diferentes significantes para um só significado: o conceito de cachorro, definindo um tipo de mamífero carnívoro de quatro patas, geneticamente semelhante à família dos lobos que há muito tempo foi domesticado pelo ser humano.

A figura 4 demonstra que a significação será eficaz quando o receptor conseguir associar ao sinal recebido a mesma intenção gerada pelo emissor, devendo necessariamente compreender/ entender a temática abordada, ocorrendo enfim, a comunicação. 
Figura 4 - Teoria da comunicação.

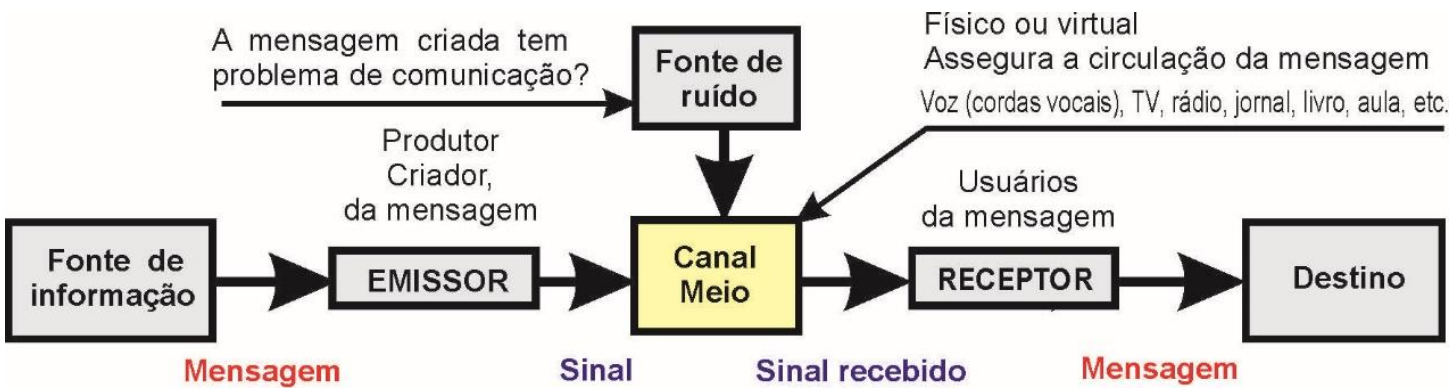

Figura realizada pelo autor baseada em HALL (2012).

O signo ainda se relaciona com o objeto de maneiras distintas, baseando-se em três tipos de experiências vivenciadas pelo receptor (PIERCE, 2012):

- Ícone - representa o objeto do mundo real por semelhança (física). Por ex.: o desenho de uma casa, a caricatura de uma pessoa, a foto de uma cachoeira, a placa de rua que faz uso de pictogramas para indicar onde se localiza o zoológico, aeroporto, restaurante, etc.

- Índice - representa o objeto do mundo real por proximidade (sugestão) ao invés de representá-la. Por ex:: quando se vê uma planta baixa (em arquitetura), presume-se que é uma casa; pegadas na areia alertam que pessoas passaram recentemente pela praia; uma placa com um pictograma ao representar uma cadeira de rodas adverte que naquele lugar só pessoas com deficiências especiais devem estacionar.

- Símbolo - representa o objeto do mundo real tendo como referência o uso não questionável do signo, pois são (simplesmente) aceitos pela sociedade através de pactos coletivos, culturais. Pergunta: Alguém já viu um rio que tivesse a cor azul clara? A maior parte dos rios não possui essa coloração (barrento, amarelado, marrom-esverdeado), mas por convenção social desenhos de crianças e mapas utilizam a cor azul clara para comunicar cursos d'água. Um símbolo ainda pode ser abstrato/convencional quando não possui semelhança(s) física(s), mimética(s) em relação ao elemento representado, como, por exemplo, uma bandeira que remete a um país, a cruz vermelha que remete a hospital, posto de saúde, ou traço ponto que remete a fronteira entre municípios. Por outro lado, um signo pictórico-icônico-figurativo deve possuir semelhança(s) física(s)/mimética(s) em relação ao elemento representado.

Portanto, o signo é composto por diferentes graus de abstração da realidade, ou seja, apresenta menor abstração quando a imagem (física) tiver maior semelhança com o objeto representado e viceversa. A figura 5 demonstra três graus diferentes de abstração.

Figura 5 - Graus de abstração da realidade.

\begin{tabular}{|c|c|c|c|c|c|c|}
\hline Autor & Simbolo & Desenho & Simbolo & Desenho & Simbolo & Desenho \\
\hline $\begin{array}{l}\text { Oliveira } \\
\text { (1977) }\end{array}$ & Arbitrário & & $\begin{array}{c}\text { Semi } \\
\text { natural }\end{array}$ & & Natural & \\
\hline $\begin{array}{l}\text { Gerber, } \\
\text { Burden } \\
\text { e Stanton }\end{array}$ & Abstrato & & Associativo & & Pictórico & \\
\hline $\begin{array}{l}\text { Forrest } \\
\text { e Castner } \\
(1990)\end{array}$ & Arbitrário & & $\begin{array}{c}\text { Signo } \\
\text { motivado }\end{array}$ & & $\begin{array}{l}\text { Imagens } \\
\text { relatadas }\end{array}$ & \\
\hline
\end{tabular}


Ao se levar em consideração as diferentes formas de se representar o signo, Carneiro (2001) ressalta que o processo comunicativo é fundamentalmente baseado em duas condições: o canal deve ser rico o bastante para não ter ruídos, e o sinal deve fazer parte de um repertório comum à fonte do produtor-emissor e do receptor-usuário. Consequentemente, é imprescindível ao ato de comunicar o uso das linguagens verbal e/ou não verbal.

Devido a sua estrutura sintética, a linguagem verbal - que faz uso da palavra falada ou escrita - é dotada de recursos que instrumentaliza a alfabetização do ser humano em um processo dividido em etapas, pois conta com uma estrutura relativamente bem organizada. Segundo Dondis (2015), primeiro se aprende um sistema de símbolos (linguísticos) sonoros, representados por formas abstratas de determinados sons: o alfabeto. O segundo passo é aprender as combinações das letras e de seus sons, formando assim as palavras, que se constituem como representantes ou substitutos das coisas, conceitos e ações. Ao final se estabelece uma sintaxe comum (idioma específico: português, inglês, russo) que limita o alfabetismo verbal em uma estrutura dotada de planos técnicos e definições consensuais. Paiva (2010) complementa que a linguagem verbal é capaz de articular ideias complexas, apresentando as informações com maior precisão, riqueza de detalhes, e por isso, é mais densa, lenta, devendo haver a interpretação de texto. Por ex.: a imagem do copo com o líquido transparente - que poderia ser água... - vem em uma manchete que diz: "O aumento do alcoolismo nos lares brasileiros".

Todavia, a comunicação será realmente eficaz em certo idioma, ou seja, somente para aqueles que o dominarem, até porque, mesmo a língua inglesa (a mais falada em todo o mundo) não consegue alcançar efetivamente todos os povos/ pessoas.

Enquanto a comunicação visual (linguagem não verbal) se caracteriza pelo uso de símbolos que transmitem mensagens de objetos, conceitos, ações a partir de imagens (diretas) como, desenhos, gestos, cores, fotografia, vídeos, pictogramas, etc. No entanto, a interpretação do símbolo é "muda", sem um direcionamento. Por ex.: ao se deparar com uma foto ou desenho que revela uma vegetação com muitas cactáceas, solo arenoso, forte luz amarela e alaranjada, é fácil entender que estamos em uma região de clima semiárido, seco. Um texto não seria tão direto, pois o ambiente natural é percebido por um olhar.

Em termos comparativos, a comunicação (alfabetismo) visual tem uma abrangência mais universal, ao fazer uso de conjuntos lógicos, facilmente obtidos por meio dos diversos níveis de experiências diretas ao ato de ver e reconhecer, por exemplo, uma casa, árvore, montanha, um animal, carro, etc. Tal capacidade amplia paulatinamente o conhecimento da realidade-concreta do indivíduo, que generaliza toda uma espécie a seus atributos básicos, ou seja, o tipo pássaro, homem, árvore, praia, mulher, girafa, tubarão, etc. são definidos em termos visuais elementares, sendo identificados em uma forma geral. Isto significa que todos os elementos compartilham referências visuais comuns dentro de uma categoria mais ampla (DONDIS, 2015).

No entanto, Dondis (2015) ressalta que é importante refletir sobre uso da palavra alfabetismo em relação ao contexto da linguagem não verbal, pois mesmo que a visão seja algo natural, a criação e compreensão de mensagens não verbais são eficazes até certo ponto. A plena eficácia também só é alcançada através do aprendizado, ou seja, expandindo as capacidades de "ver" (formar imagens mentais), que significa ampliar a capacidade de entender e criar uma mensagem visual. Por isso, essa forma de comunicação deve ser aprendida tanto na educação formal quanto informal, sendo paulatinamente incorporada à vida das pessoas a partir das experiências compartilhadas no ambiente escolar e na sociedade como um todo, fazendo com que o indivíduo possa manter uma relação comunicativa mais ampla com o mundo.

Apresenta-se assim, alguns exemplos que são assimilados por meio da comunicação visual: hidrografia, azul-claro nos mapas; árvores, verdes e verticais; areia, áspera e fofa; terra úmida, fogo vermelho-alaranjado, noite e o dia (claro-escuro), desenho de um cubo de gelo no papel (apreensão do conceito da perspectiva, volume), entre outros. Há também o mundo criado: a luz amarela do semáforo exigindo atenção, uma placa representando um garfo e uma faca indicando a direção do restaurante, uma seta para direita apontando a direção, etc. Portanto, a humanidade aprende instintivamente a compreender e a atuar psicologicamente no mundo e, intelectualmente, convive e opera com ambientes e objetos necessários à sua sobrevivência. Conscientemente ou não, as

$\begin{array}{llll}\text { Caminhos de Geografia } \quad \text { Uberlândia-MG } & \text { v. 21, n. } 75 \quad \text { Jun/2020 } & \text { p. 117-136 Página } 123\end{array}$


sociedades respondem com alguma conformidade ao significado dos elementos visuais (DONDIS, 2015).

$\mathrm{Na}$ figura 6, Fiori (2011) descreve os seis elementos básicos da comunicação visual: linha (construção de formas bidimensionais como o círculo, quadrado, triângulo), volume (suposta tridimensão - perspectiva como a esfera, o cubo, o cone, pirâmide), luz (sombreamento, volume), cor (reforço visual), textura (distinção visual dos elementos da imagem) e a proporção/ escala.

O uso em conjunto desses elementos visuais proporciona uma grande variedade de formas de expressão, por exemplo, croqui de um desenho feito a lápis, pintura de uma mata tropical e úmida em óleo sobre tela, foto de uma paisagem paradisíaca em um folder turístico, ambiente assustador em um filme de terror, recorte de uma imagem de satélite do Google Earth.

Neste contexto, Dondis (2015) critica o sistema educacional formal (em todos os níveis) por tratar a abordagem visual com quase desinteresse. Métodos construtivos de aprendizagem visual são pouco explorados e ficam a critério da intuição e do acaso, a não ser quando se trata daqueles alunos especialmente interessados e talentosos para o desenho. A sociedade persiste ainda em conferir mais importância à expressão verbal, excluindo o restante da sensibilidade humana. No caso da criança, a experiência visual é fundamental em sua aprendizagem. Posteriormente, a utilização de recursos visuais - filmes, ilustrações, slides, projeções audiovisuais - carecem de rigor e objetivos bem definidos no ensino, sendo usados somente como apresentações que reforçam sua experiência passiva. Em suma:

[...] a comunicação visual ficou ao sabor das fantasias e de amorfas definições de gosto, quando não da avaliação subjetiva e auto-reflexiva do emissor ou do receptor, sem que se tente ao menos compreender alguns dos níveis recomendados que esperamos encontrar naquilo que chamamos de alfabetismo no modo verbal (DONDIS, 2015, p.17).

Dondis (2015, p. 19) ainda pondera: no geral: "o alfabetismo visual jamais poderá ser um sistema tão lógico e preciso quanto a linguagem verbal, pois sua estrutura tem uma lógica que o alfabetismo visual é incapaz de alcançar".

Por outro lado, a compreensão da linguagem não verbal é um processo natural. O necessário a ser feito é um refinamento de percepção do alfabetismo visual. O caminho não é o mesmo que o da linguagem verbal, onde existe um signo substituto que precisa ser reduzido a uma sintaxe comum (alfabeto, idioma). No ato perceptivo visual ${ }^{3}$, uma "melancia" é a mesma coisa tanto para um inglês quanto para um espanhol ou um finlandês, ainda que o primeiro a chame de watermelon, e o segundo de sandía e terceito vesimeloni. Em suma, o que a linguagem verbal difere da comunicação visual é a possibilidade de evitar a ambiguidade das pistas visuais, tentando então, expressar as mensagens de modo mais simples e direto. A sofisticação excessiva e a escolha de um simbolismo complexo podem trazer dificuldades na comunicação visual (Dondis, 2015).

Partindo da dualidade e potencialidades da linguagem verbal e comunicação visual, defende-se um tipo específico de desenho: o ilustrativo, que faz uso tanto da figura pictórica (que atrai, torna a informação menos abstrata pelo uso do desenho figurativo) quanto do texto (que traz precisão ao conteúdo a ser informado), estabelecendo-se assim, um instigante recurso didático que pode auxiliar no processo de ensino-aprendizagem.

\section{ILUSTRAÇÃO E POSSIBILIDADES NA GEOGRAFIA: DESENVOLVIMENTO E USO}

O estudo do desenho ilustrativo (ou simplesmente ilustração) enquanto forma de comunicação visual é um recurso didático que se estabelece como uma linguagem mista, isto é, caracteriza-se pela junção das linguagens verbal e não verbal (Figura 7).

\footnotetext{
${ }^{3} \mathrm{Na}$ percepção visual, a pessoa vivencia uma interpretação direta daquilo que vê. "Todas as unidades individuais dos estímulos visuais interagem, criando um mosaico de forças saturadas de significado, exclusivo do alfabetismo visual e passível de ser diretamente absorvido com muito pouco esforço, se comparado à lenta decodificação da linguagem verbal". A inteligência visual transmite informação em uma extraordinária velocidade, tanto que, estando os dados claramente organizados e formulados, a informação fica mais fácil de ser absorvida, retida e utilizada referencialmente (DONDIS, 2015). 
Figura 6 - Os seis elementos básicos da comunicação visual.
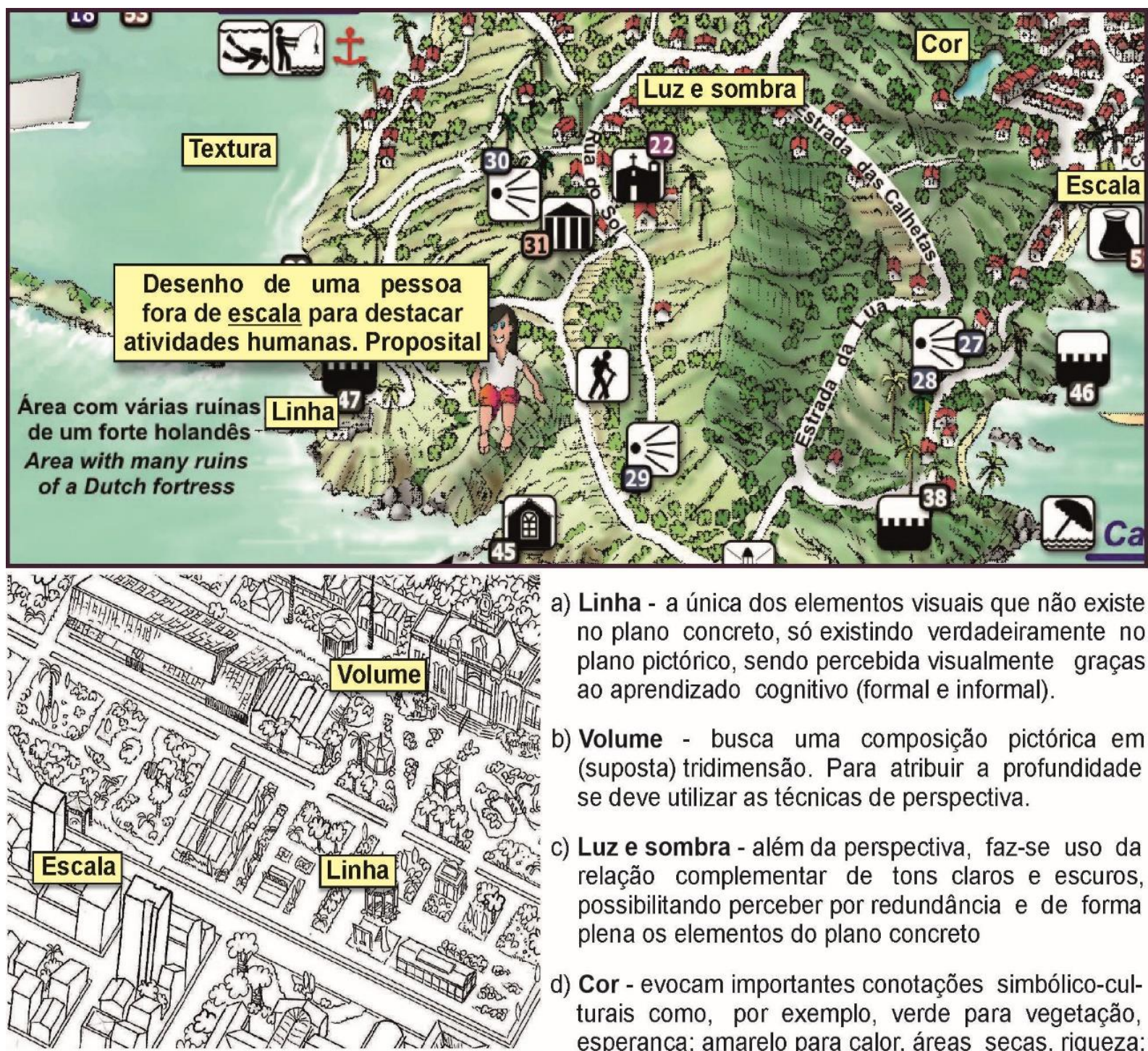

a) Linha - a única dos elementos visuais que não existe no plano concreto, só existindo verdadeiramente no plano pictórico, sendo percebida visualmente graças ao aprendizado cognitivo (formal e informal).

b) Volume - busca uma composição pictórica em (suposta) tridimensão. Para atribuir a profundidade se deve utilizar as técnicas de perspectiva.

c) Luz e sombra - além da perspectiva, faz-se uso da relação complementar de tons claros e escuros, possibilitando perceber por redundância e de forma plena os elementos do plano concreto

d) Cor - evocam importantes conotações simbólico-culturais como, por exemplo, verde para vegetação, esperança; amarelo para calor, áreas secas, riqueza; azul para corpos d'água, ambiente tranquilo; verme-

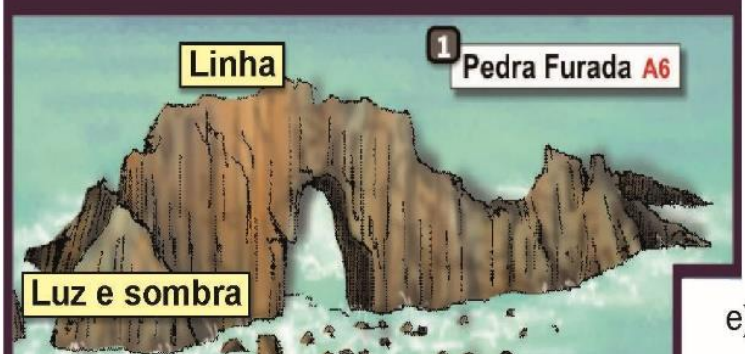
Iho para áreas quentes ou com grande densidade humana, etc.

Além disso, a intensidade das cores (frias e quentes) possibilitam "distâncias visuais" por brilho e contraste, isto porque, a superfície mais clara sempre aparecerá maior, pois a luz refletida lhe confere amplidão

e) Textura - elemento visual muito útil na substituição ou complementação das qualidades de um outro sentido: 0 tato, pois texturas possuem padrões. Imagine a textura de um tipo de madeira ou tecido, de uma praia com areia fina ou cascalhos, de um mar de águas quentes ou congelado.

Assim, uma textura possui qualidades táteis e óticas, permitindo à mão e ao olho uma sensação individual

f) Escala - auxilia na composição de tamanhos e proporções entre dois ou mais elementos visuais no desenho. Além disso, é muito útil para definir os planos em um desenho. 
Figura 7 - A ilustração como linguagem mista.

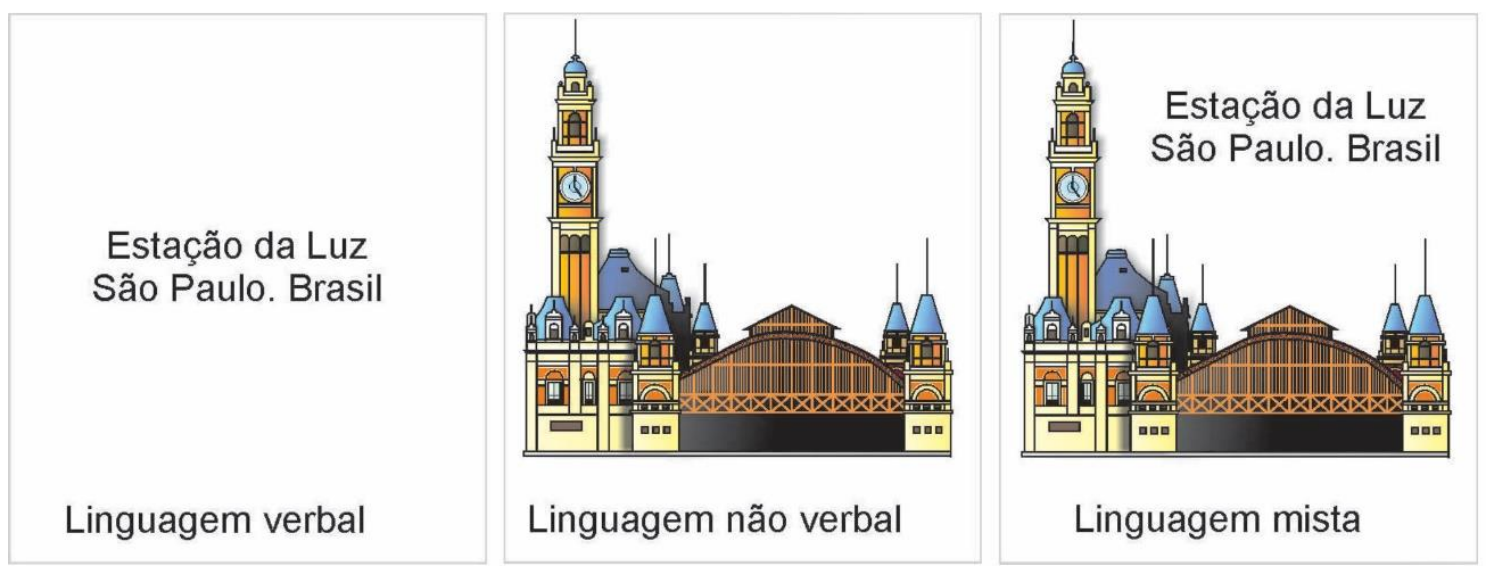

Figura realizada pelo autor.

Diferentemente do desenho artístico, a ilustração sempre está associada a um texto, havendo uma relação de dependência mútua na qual o texto complementa a imagem e vice-versa (PAIVA, 2010). Arbach (2011) então ratifica que o desenho ilustrativo leva em conta os dois universos discursivos (verbal e não verbal), que interagem, dialogam entre si. Além disso, esta tipologia de desenho é realizada a partir de um processo de simplificação do plano concreto, visível, enfatizando aspectos do elemento representado de forma mimética, icônica (ARAÚJO, 2012).

Biondo, Costa e Brito (2008) complementam que a ilustração serve para elucidar as informações de um texto devido ao seu alto poder de síntese. Imagine a quantidade de texto necessária se não houvesse os desenhos na figura 8 !

Figura 8 - A ilustração como informação de síntese.

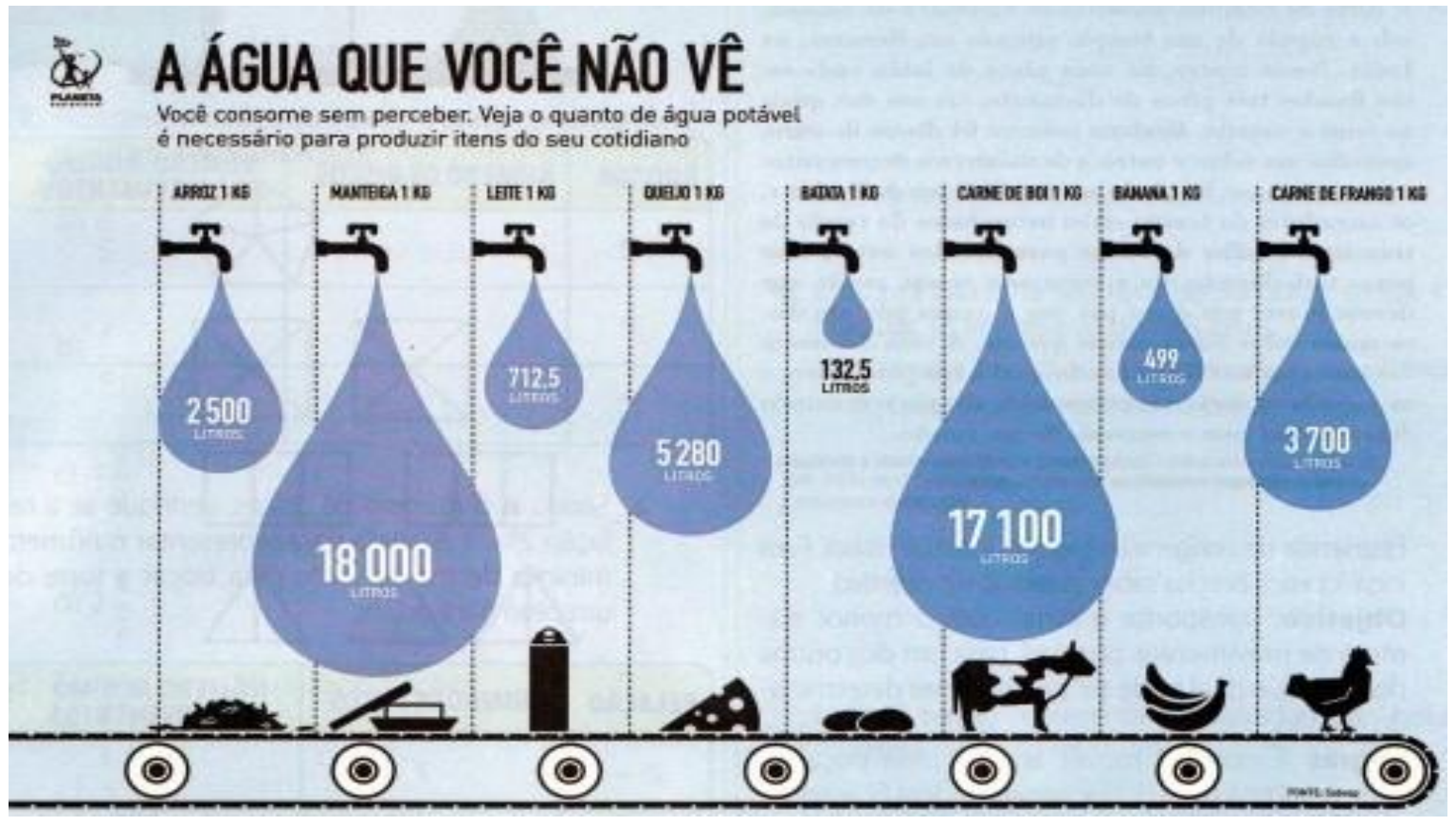

Fonte: VIVO VERDE (2019).

A figura 9 demonstra que a ilustração é um tipo de desenho que precisa informar eficazmente seu público potencial, ou seja, a relação imagem e texto não permite ambiguidades para se compreender o conteúdo, auxiliando assim, a explicar, complementar, exemplificar o texto - Figura 10. 
Figura 9 - Ilustração é um dos tipos de desenho.

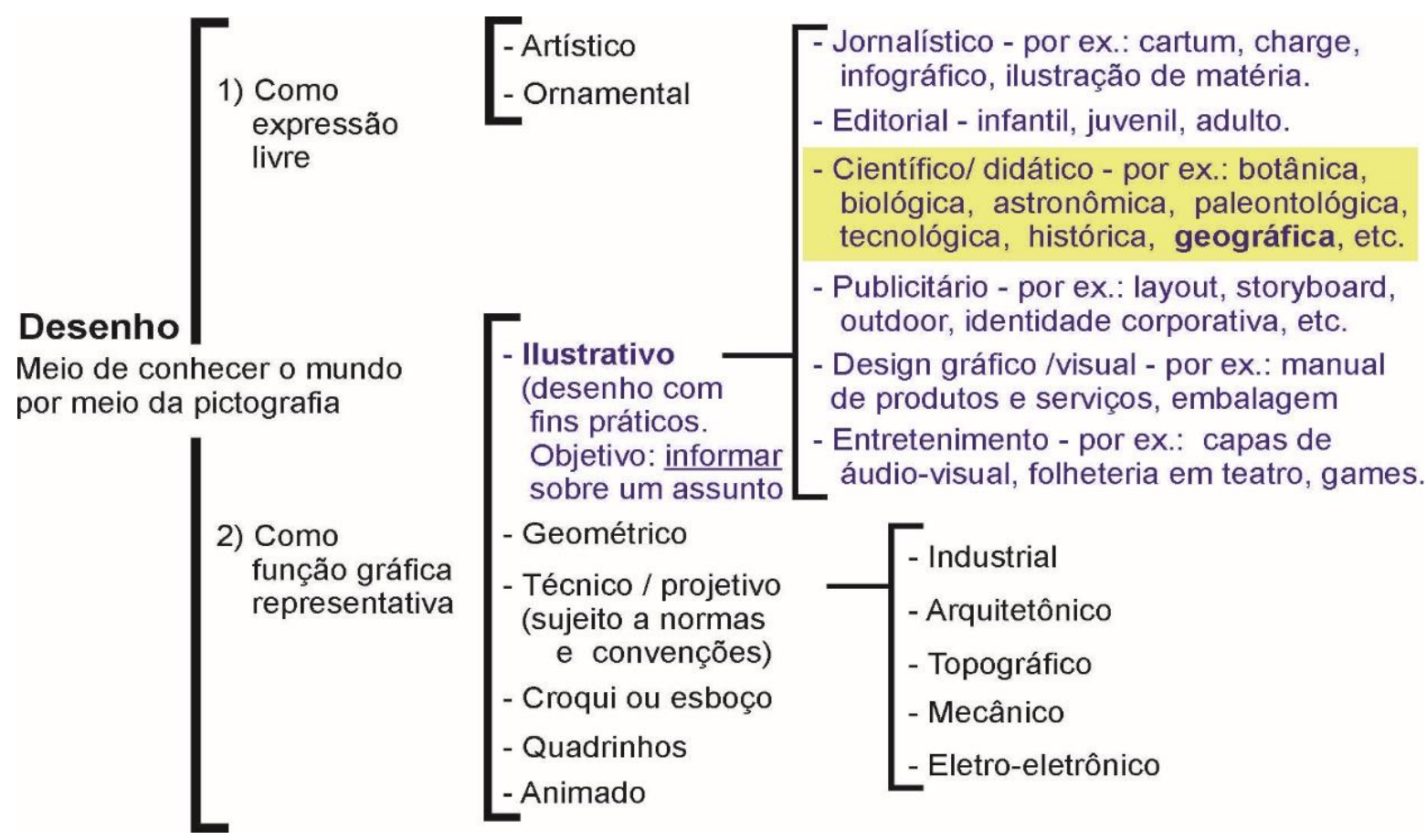

Figura realizada pelo autor baseada em CABANELLAS (1976) e HALL (2012).

Figura 10 - A ilustração informativa.

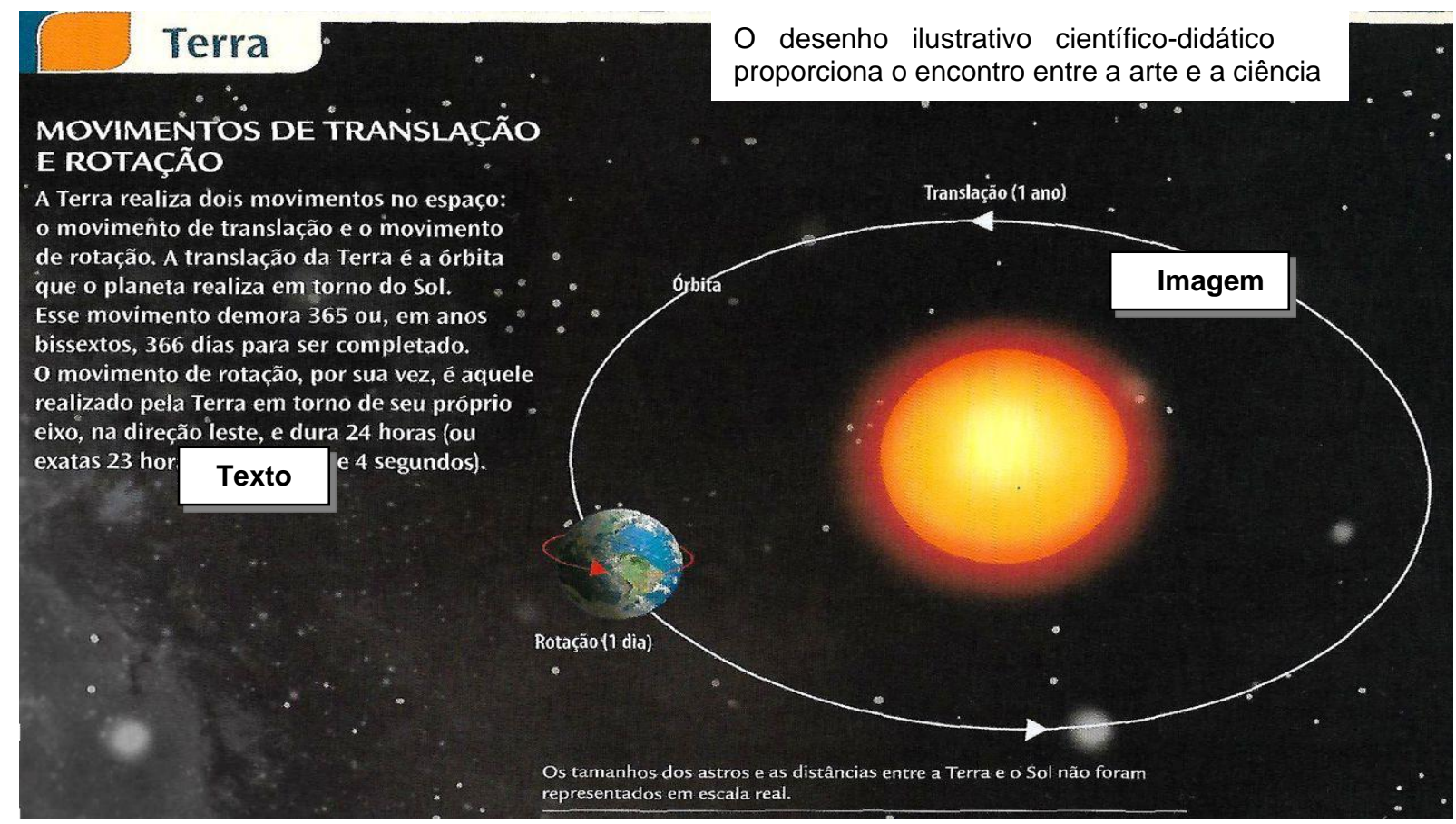

Fonte: OXFORD (2013, 15p).

Portanto, a ilustração permite maior vigor à mensagem, abrindo espaço para que o recurso gráfico seja utilizado pelo professor, que pode ministrar aulas, realizar debates utilizando mais de um instrumento didático a partir de um mesmo objeto de estudo, tornando as aulas mais dinâmicas e instigando o pensamento crítico do aluno. Em outras palavras, cabe ao professor mediar o processo de aprendizagem, utilizando-se de estratégias que levem o aluno a se tornar mais independente e 
estimule o conhecimento potencial, de modo a criar uma nova zona de desenvolvimento proximal ${ }^{4}$ a todo o momento.

Neste contexto, a ilustração possuidora de uma comunicação mais direta, concisa, e "informal", pode ser empregada como um recurso gráfico eficaz no processo de aprendizado (FIORI, 2011). Souza (2007) define recurso didático como qualquer material que auxilie no processo de ensinoaprendizagem do conteúdo a ser transmitido pelo professor. A proximidade do aluno com o material didático serve para motivar a participação e interesse pela informação, contribuindo assim, para a apreensão de informações e uma melhor interação entre os próprios estudantes, pois nessa forma de aprendizado podem partilhar suas dúvidas, entendimentos, questionamentos acerca do conteúdo trabalhado.

Não por acaso, as ilustrações facilitam o processo da formação de conceitos pelas funções superiores do indivíduo, caracterizadas por capacidades humanas como a atenção, memória e percepção (VIGOTSKI, 1993). Andreis (2012) afirma que quando as funções superiores são de certa forma alcançadas, ao invés do intelecto estar a serviço da memória, é a memória que serve ao intelecto para potencializá-lo e atribuir sentido ao conceito.

A memorização é importante para entender como se estrutura o aprender, pois serve para a criação de paralelos que permitem a criação de análises mais generalizantes e abstratas, em um processo de descolamento do concreto que dá ao intelecto o controle intencional das análises em escala (ANDREIS, 2012). Daí a importância da ilustração enquanto recurso acadêmico-escolar. A figura 11 apresenta dois mapas físicos da América do Sul com graus de abstração da realidade diferentes (FIORI, 1999). Imagine o quanto é difícil para um estudante do sexto ano do Ensino Fundamental olhar as cores verde, laranja, marrom e imaginar a altitude (baixa /alta). Assim, no processo de formação do discente, pode-se se iniciá-lo a partir de um mapa ilustrativo com suposta tridimensão.

Figura 11 - Construção do conceito a partir dos graus de abstração da realidade.

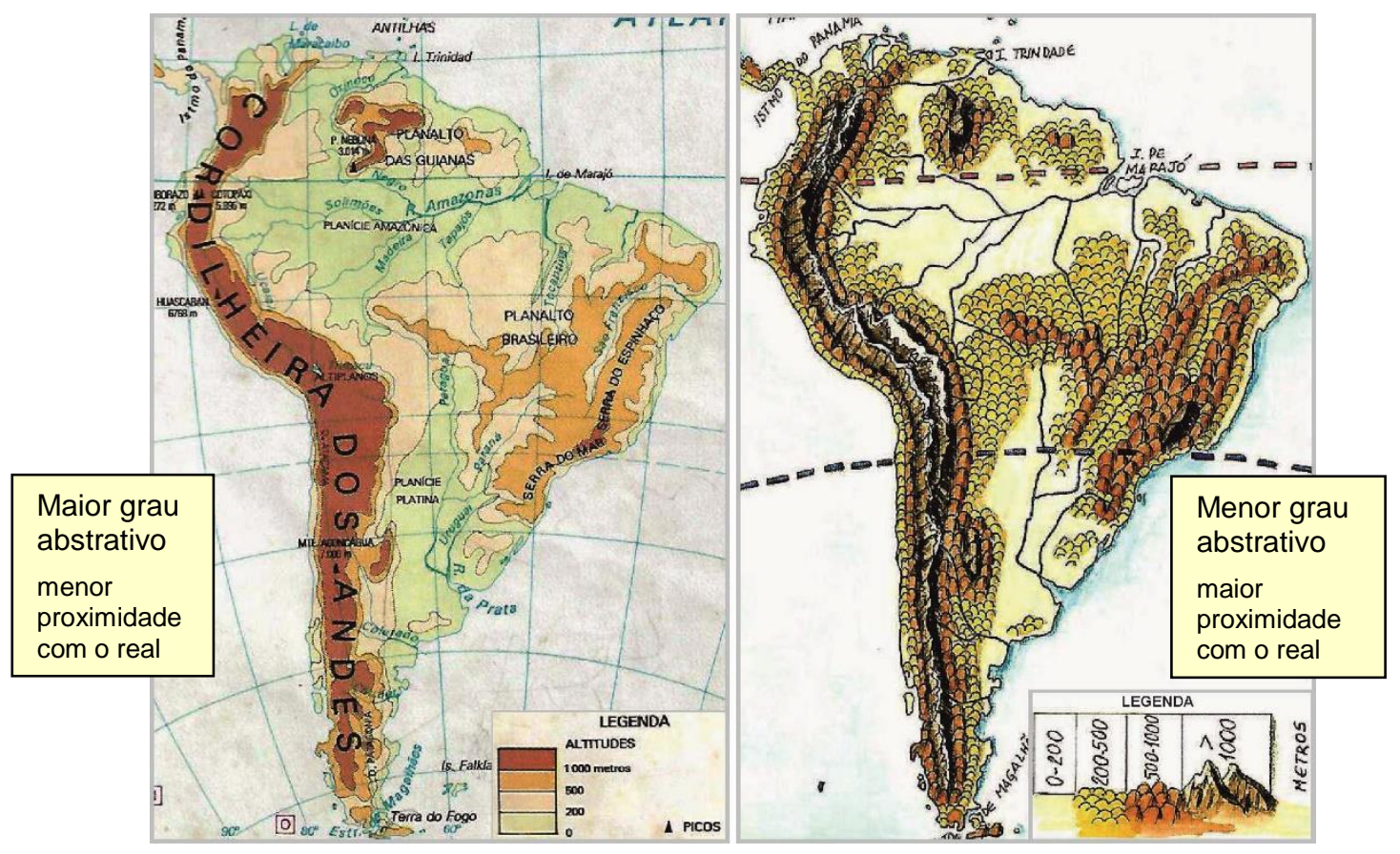

Fonte: Simielli (1993, p. 26).

Fonte: Fiori (1999, p. 67).

\footnotetext{
4 Entende-se por zona de desenvolvimento proximal, a distância entre aquilo que o sujeito já sabe: o conhecimento real; e aquilo que o sujeito possui potencialidade para aprender: o conhecimento potencial. Dessa forma, a aprendizagem na zona de desenvolvimento proximal necessita do auxílio de outros (recursos didáticos, profissionais) para que a informação possa ser apreendida.
}

\begin{tabular}{|c|c|}
\hline Caminhos de Geografia & Uberlândia-MG \\
\hline
\end{tabular}


O intuito da pesquisa (FIORI, 1999) foi trabalhar com representações não convencionais, ou seja, fazer uso do desenho pictórico que, somado à visão oblíqua ${ }^{5}$, busca facilitar o processo de abstração do receptor-usuário potencial (estudante do Ensino Fundamental I / $6^{\circ}$ ano), gerando um maior interesse e apreensão das informações contidas no mapa.

No geral, os resultados da pesquisa empírica confirmaram a aceitação dos produtos cartográficos propostos. Um exemplo foi o comentário da professora que aplicou o teste com os mapas a cento e vinte crianças: "Elas demoraram mais para responder o questionário dos mapas pictóricos, por ficar um tempo maior observando, conversando entre eles. Ficaram muito interessados". Por isso, o objetivo foi alcançado, principalmente por conceber um tipo de representação que motivou o aluno à leitura do mapa. Além disso, a decodificação (leitura) das representações elaboradas conseguiu ser eficaz aos estudantes (por volta de $80 \%$ de respostas corretas), devido ao fato de a informação estar mais próxima da realidade do público pesquisado (FIORI, 1999).

Mesmo assim, Silva et al. (2002) advertem que trabalhar com a arte no ensino de Geografia é um tanto utópico, pois mesmo não sendo um recurso novo em sala de aula, ainda é pouco empregado pelos docentes. Isto porque, o uso do recurso demanda do professor conhecimentos em outra área de estudo.

Entretanto, a aquisição de métodos e técnicas relacionadas à pictografia pode contribuir para a formação do discente, ampliando os instrumentos didáticos de apreensão do conteúdo programático, principalmente em áreas como a cartografia, geomorfologia, pedologia, hidrografia e biogeografia. Caso o professor/aluno não sinta apto para elaborar ilustrações, é importante ressaltar que o assunto discutido nesse artigo não deve servir como fator desestimulador, pelo contrário, podem-se utilizar ilustrações, desenhos, mapas já prontos em livros, Atlas, internet e adaptá-los de acordo com os conteúdos das atividades propostas.

A seguir, apresentam-se outros exemplos sobre a importância (desenvolvimento, uso) da ilustração em trabalhos escolares, acadêmicos e profissionais (ensino, pesquisa e extensão) relacionados ao campo da Geografia.

Desde 2015, a disciplina "Tópicos Especiais em Geografia Instrumental: o uso da ilustração como recurso científico e didático" é ofertada no curso de Licenciatura em Geografia do Instituto Multidisciplinar da Universidade Federal Rural do Rio de Janeiro. A disciplina objetiva instrumentalizar alunos e futuros professores no (re)conhecimento da ilustração como importante instrumento de comunicação social, caracterizando-a como um recurso didático capaz de auxiliar na assimilação dos conteúdos programáticos. Além disso, capacita o discente a utilizar a ilustração em seus trabalhos acadêmicos e/ou profissionais. Inicialmente, o curso apresenta em atividades práticas os seis componentes pictóricos básicos (linha, volume, luz, cor, textura e proporção-escala) da comunicação visual, capacitando para o próximo passo: a elaboração de desenhos, blocos-diagrama, perfis e esquemas relacionados a temas da Geografia.

O curso tem apresentado uma boa aceitação e abre caminhos para discussões acadêmicas sobre o tema, caso do Trabalho de Conclusão de Curso (TCC) de Rodolpho Willian Alves de Lucena intitulado: "A ilustração no ensino de Geografia: proposta metodológica para elaboração e uso didático" (LUCENA, 2018). O curso também inspira uma dissertação de mestrado que trabalha a ilustração relacionada a conteúdos da climatologia. A figura 12 e 13 apresentam respectivamente algumas ilustrações desenvolvidas no TCC de Lucena (2018), e de alunos que cursaram a disciplina sobre o uso da ilustração na Geografia.

${ }^{5} \mathrm{~A}$ representação gráfica do espaço pode ocorrer de três formas:

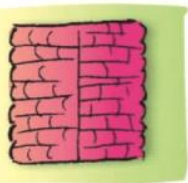

Visão vertical

Ponto de vista de cima para baixo

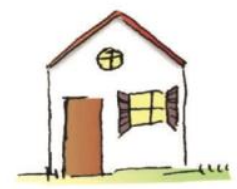

Visão frontal

Ponto de vista de frente

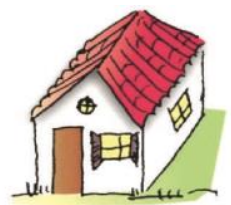

Visão oblíqua

Ponto de vista de cima e de lado 
Figura 12 - Ilustrações realizadas em TCC (LUCENA, 2018).
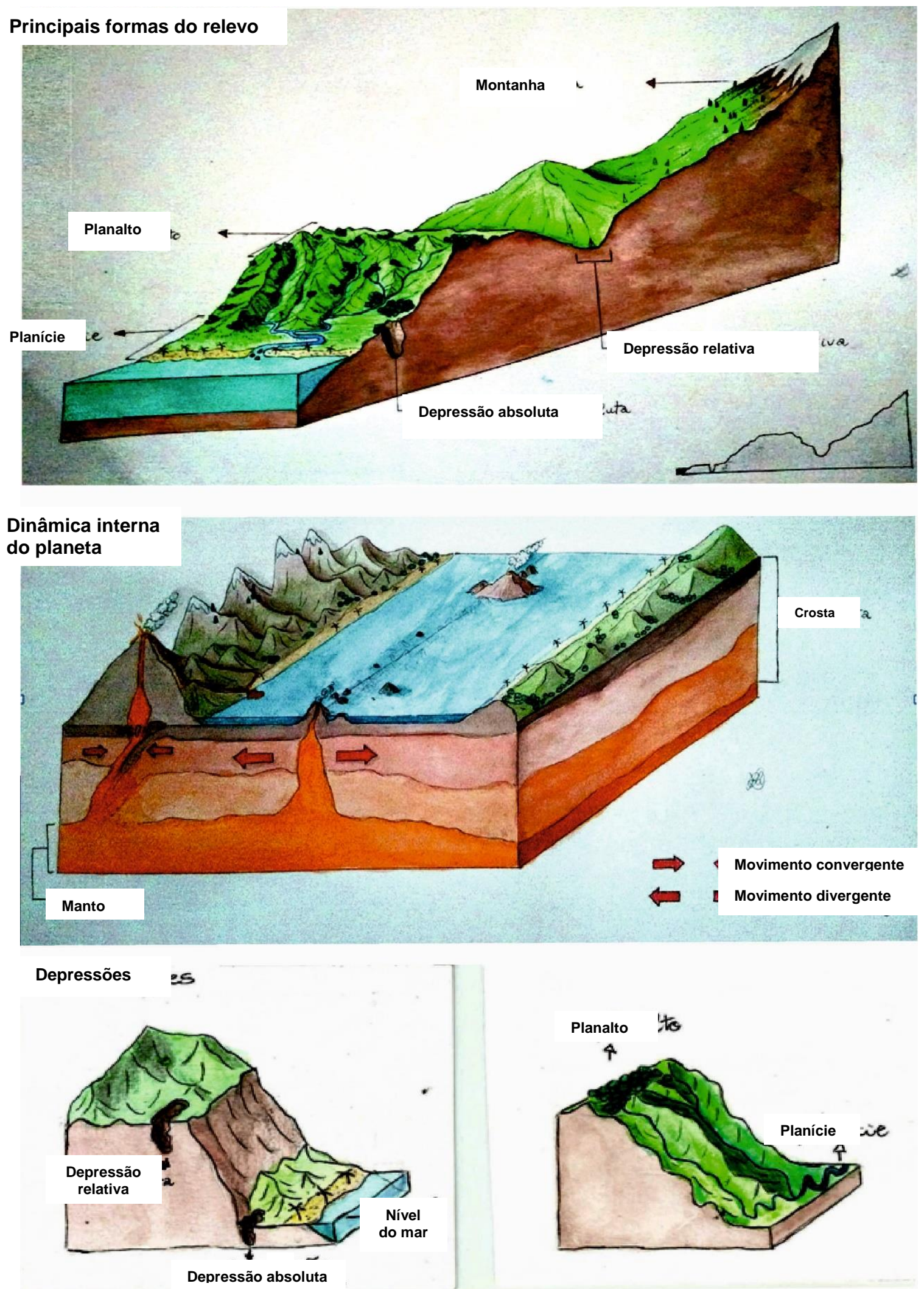

A oferta da disciplina é consequência de anos de pesquisa acadêmica (FIORI 1999, 2003, 2008), que entre seus questionamentos, percebe a necessidade de se estudar o tema da arte pictórica na Geografia com maior atenção. 
Figura 13 - Ilustrações realizadas por alunos na disciplina. "O uso da ilustração como recurso científico e didático".

\section{APARU DO JEQUIÁ}
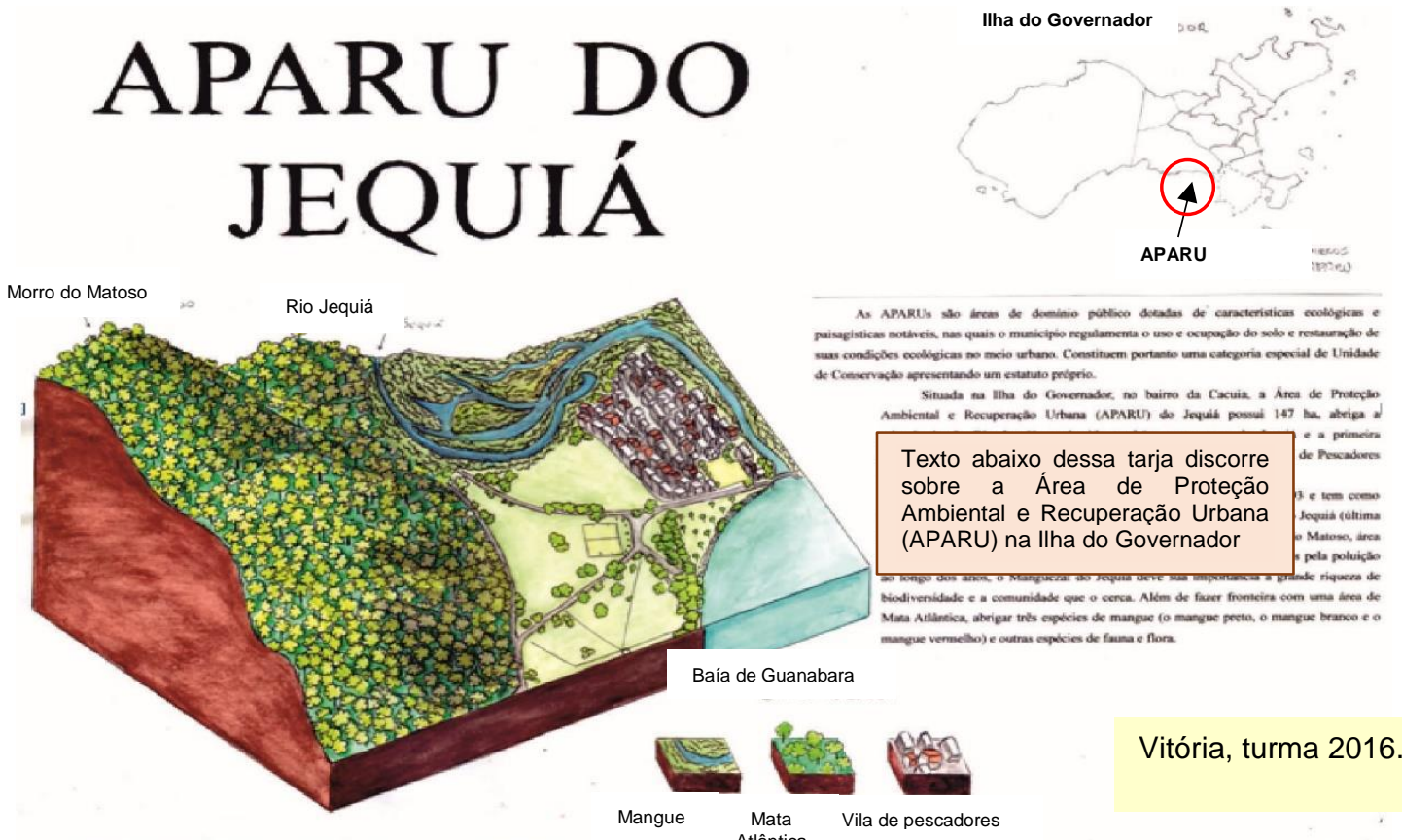

Os impactos do uso de agrotóxicos

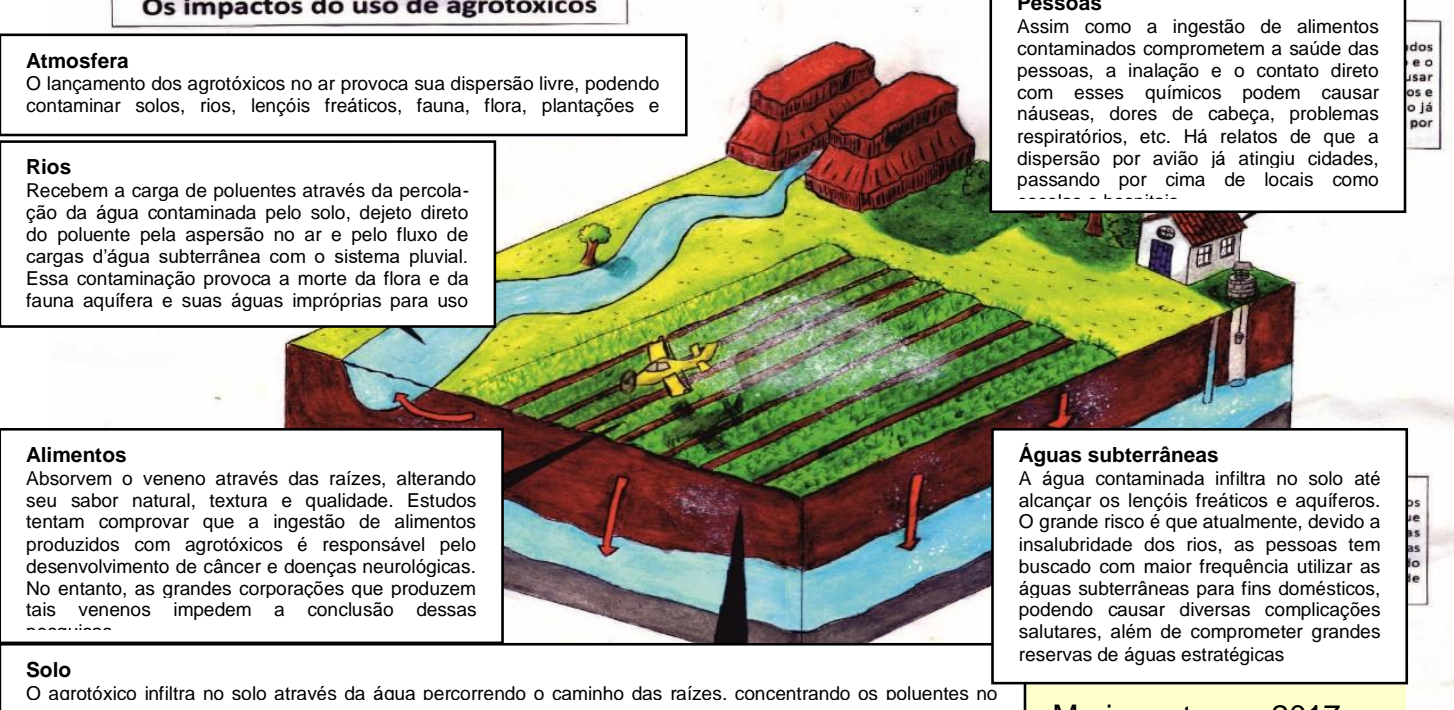

Mariane, turma 2017

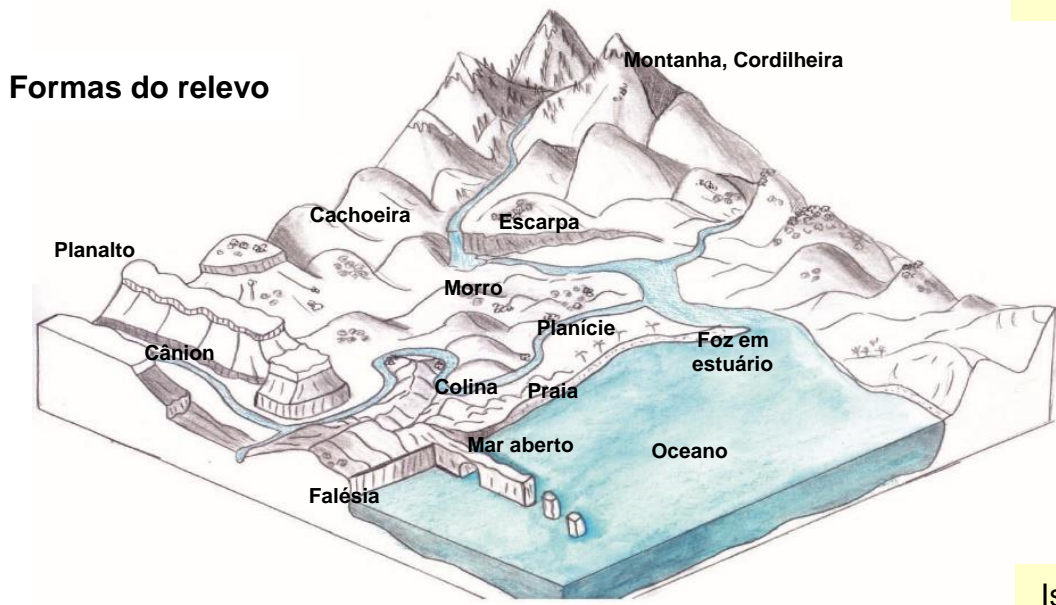

Isabella, turma 2016 . 
$\mathrm{Na}$ prática, a rica e frutífera discussão possibilitou o desenvolvimento de uma série de oficinas a professores e alunos em diversos estados brasileiros, um capítulo de livro denominado "Técnicas de desenho e elaboração de perfis" (FIORI, 2011), organizado pelo professor Luis Antonio Bittar Venturi do departamento de Geografia da Universidade de São Paulo, mais de quarenta mapas ilustrados para o turismo, além da discussão sobre o uso dos pictogramas como símbolos úteis para orientação no espaço: a sinalética (FIORI 2010 e 2014). Além de muitas ilustrações elaboradas para editoras. As citações ressaltam assim, a importância da temática pela Geografia, como se demonstra nas figuras 14,15 e 16.

Figura 14 - A ilustração na pesquisa, extensão e trabalhos profissionais.

Oficinas com professores e alunos em 2003 / DG-USP
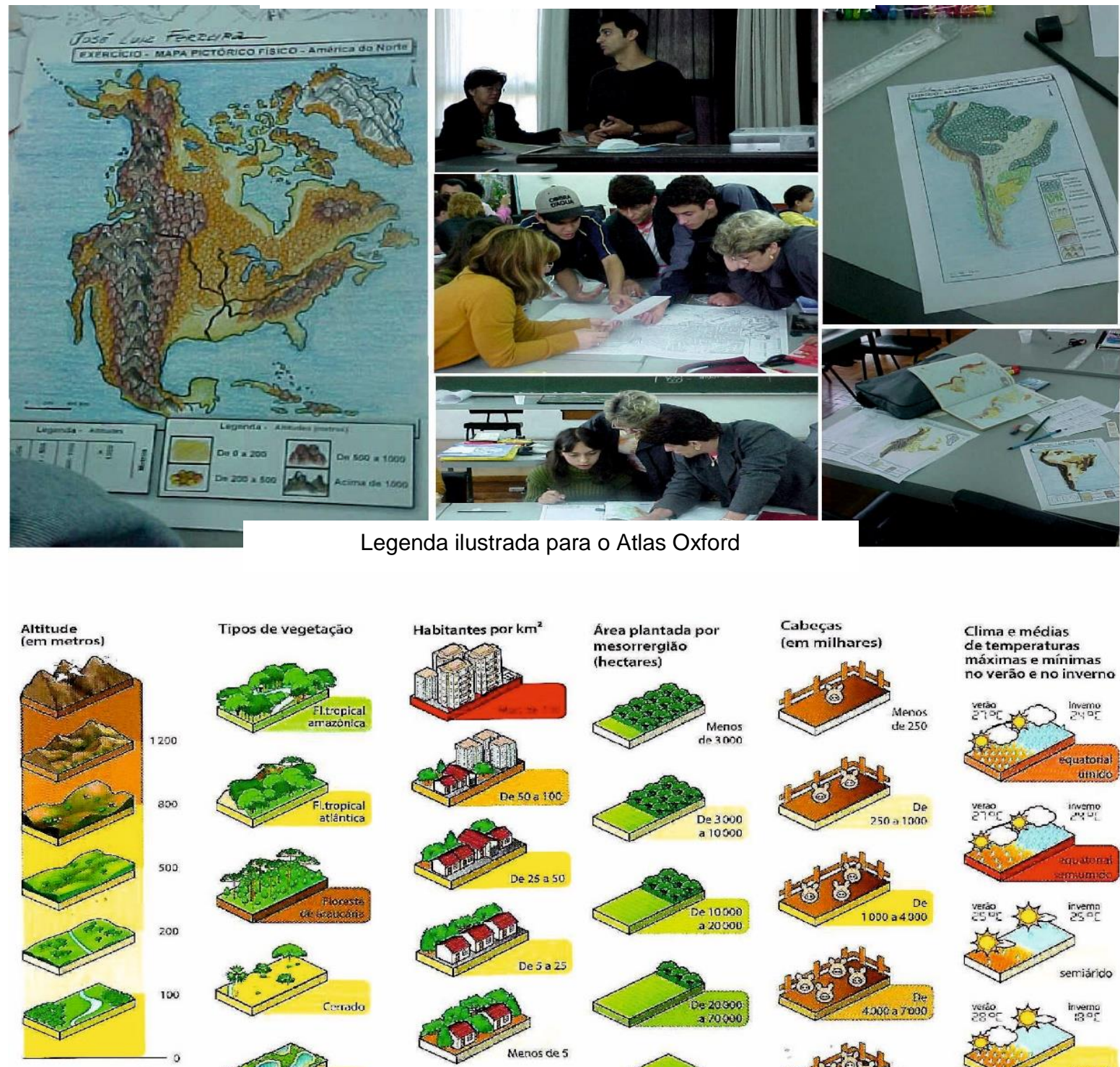

Cabeças
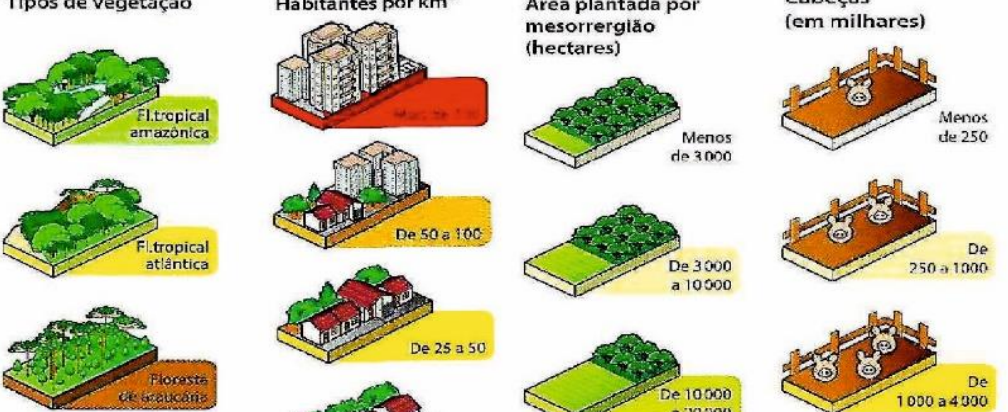

Clima e médias de temperaturas no verão e no inverno
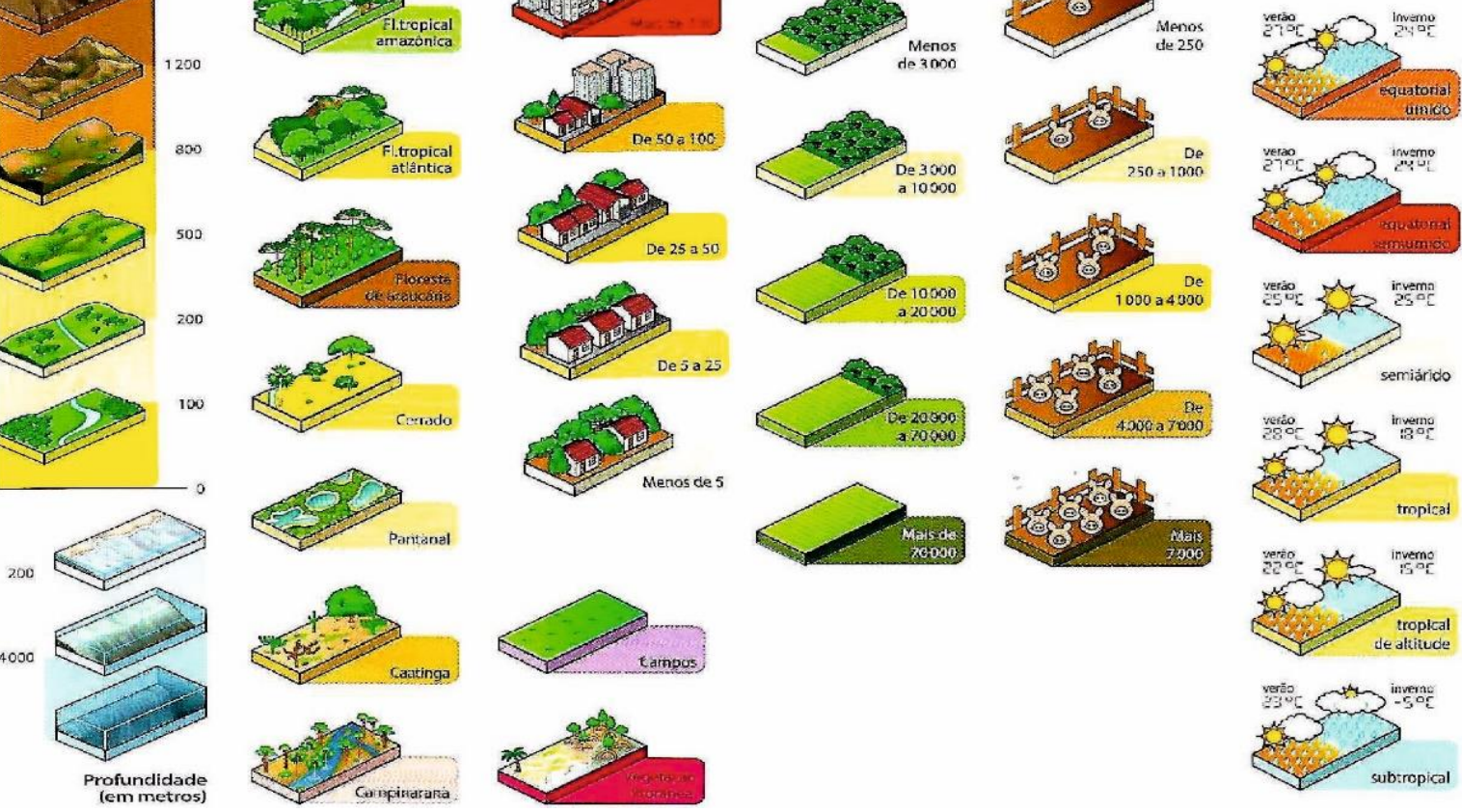

Fonte: Oxford (2013). 
Figura 15 - Mapa ilustrado do município de Caxambu, Minas Gerais.

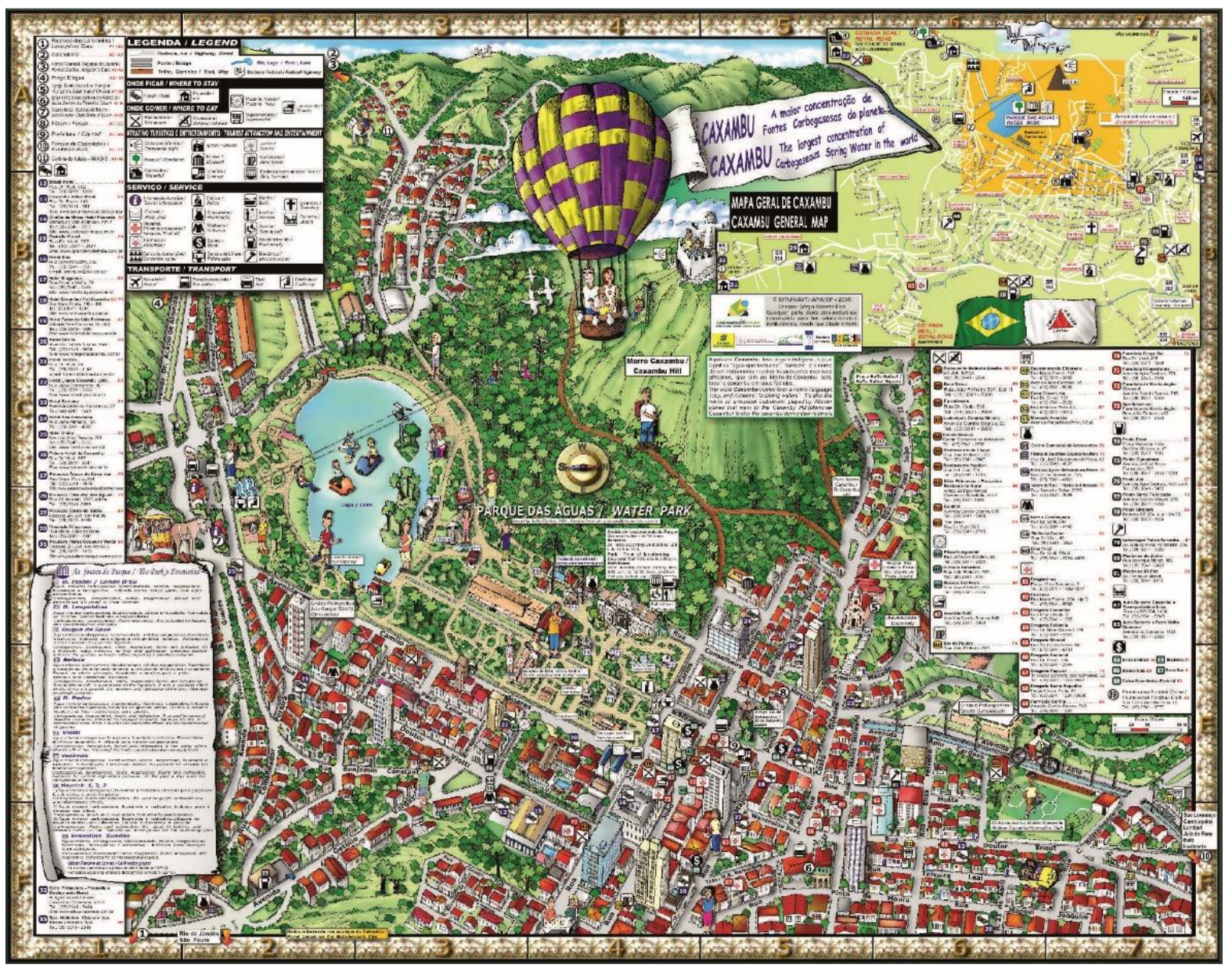

Mapa realizado pelo autor e citado em Fiori (2008).

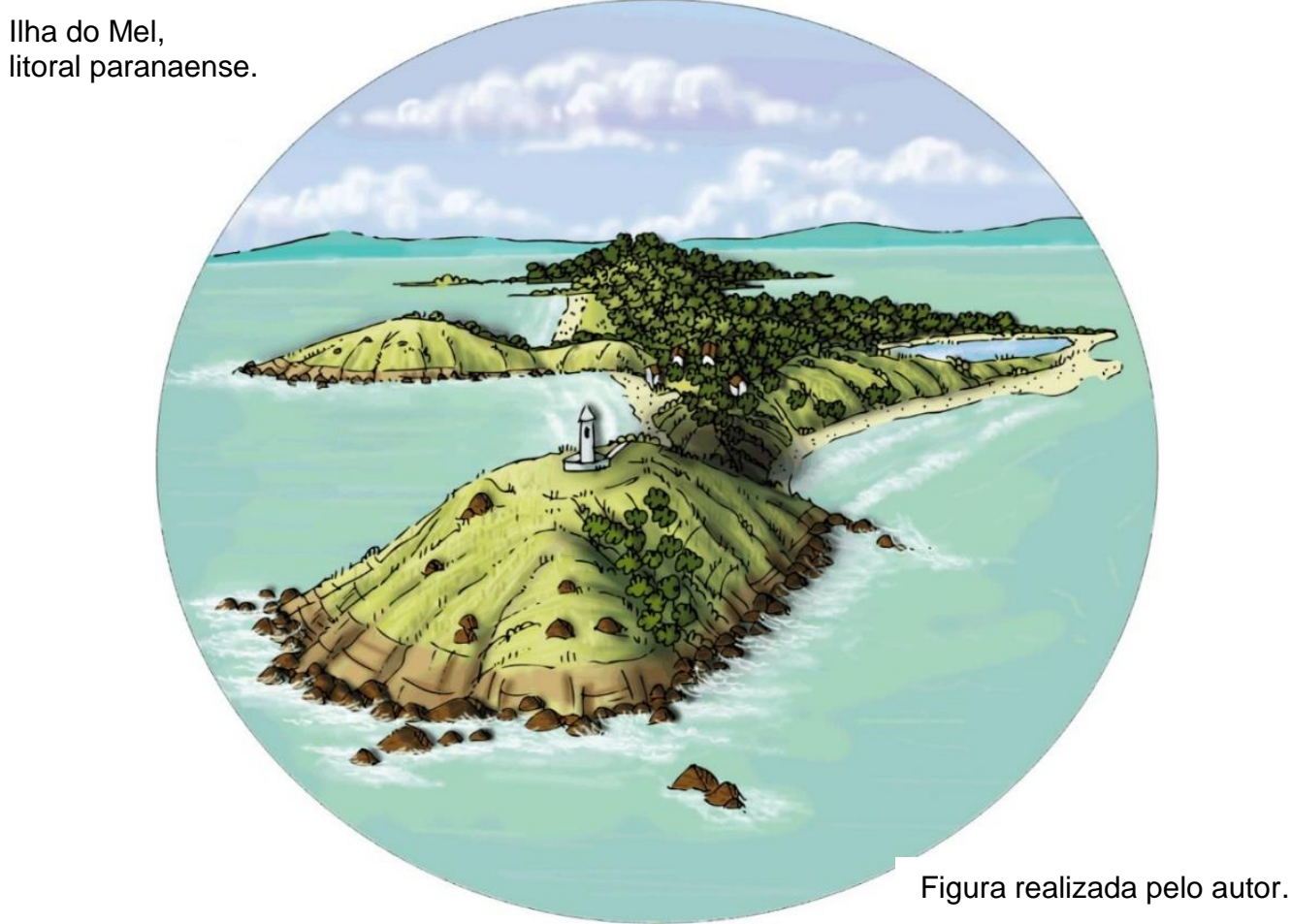


Figura 16 - Pictogramas como recurso de orientação no espaço.

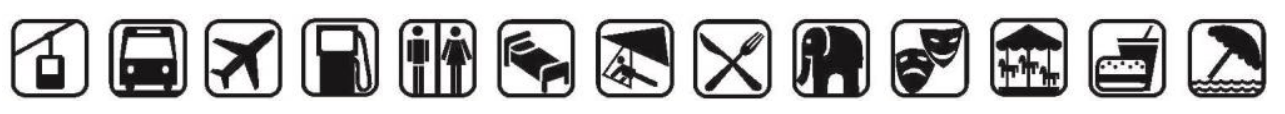

Fonte: FIORI 2008, 2010 e 2014.

Mais trabalhos podem ser vistos em dois sites pessoais: https://sergiofiori.carbonmade.com/ e http://srfiori.wixsite.com/sergiofiori.

Todos esses exemplos deixam claro que há um vasto campo de estudo e necessidades incontestáveis sobre o estudo da ilustração como um dos recursos didáticos, profissional, estabelecendo-se, ainda, como um dos instrumentos para se pensar a comunicação visual no ambiente escolar.

\section{CONSIDERAÇÕES FINAIS}

As representações pictóricas sempre fizeram parte da vida dos seres humanos - desde as pinturas rupestres em cavernas até as animações em smartphones. Aliás, devido ao grande e rápido desenvolvimento tecnológico das últimas décadas, o estudo sobre a comunicação visual se torna cada vez mais premente no mundo contemporâneo.

O artigo introduz e qualifica um tipo específico de representação gráfica: a ilustração didáticocientífica, atendo-se aos conteúdos acadêmico-escolares-profissionais estabelecidos no campo da Geografia. Diferentemente do desenho artístico, a ilustração possui uma dependência mútua e complementar entre a imagem (enquanto representação gráfica) e o texto (linguagem verbal - escrita e falada), além de outras características como a potencial vocação mimética, icônica e o grande poder de síntese da informação.

Atualmente, é muito utilizada pela mídia (impressa e digital) em revistas, livros, mapas, folders, cartazes, etc., mas o seu uso pode ser infinitamente maior e direto ao se pensar sua efetiva aplicação nas áreas de ensino, pesquisa e extensão. No entanto, tal recurso pictórico-didático parece estar a margem do processo de ensino-aprendizagem, que não dá a devida importância a ilustração, tanto em relação a capacitação de professores quanto o uso efetivo do recurso pelos alunos e profissionais da área.

Deste modo, é preciso realizar estudos mais profundos com propostas que discutam a questão do analfabetismo visual na educação, ressaltando o grande potencial dos recursos gráfico-pictóricos, os quais podem vir a ser grandes aliados no processo de aprendizado e divulgação dos conteúdos geográficos.

\section{REFERÊNCIAS}

ANDREIS A. M. Ensino de Geografia: fronteiras e horizontes. Porto Alegre: Compasso LugarCultura, 2012, $216 \mathrm{p}$.

ARAÚJO, E. A construção do livro: princípios da técnica de editoração. 2.ed., Rio de Janeiro: Lexikon, 2012, $640 \mathrm{p}$.

ARBACH, J. O discurso da ilustração. Revista A3, Universidade Federal de Juiz de Fora, Minas Gerais, ed. 1, out. 2011. Disponível em:<https://www.ufjf.br/revistaa3/todas-as-edicoes-2/revistaa301/>. Acesso em 25 jul. 2019.

BIONDO, G. J; COSTA, M. L. C. C; BRITO, S. llustração: integração de linguagens. In: BASSO, I; ROCHA, J. C. R; ESQUEDA, M. D. (Org.). Simpósio Internacional de Educação. Bauru: USC, 2008, p. 3-11.

CABANELLAS, I. Dibujo. 2.ed., Espanha: Editorial Magistério Español S.A, 1976, 180 p.

CARNEIRO, R.J.B. Sinalização turística: diretórios e sistemas nacionais e internacionais. (Dissertação de Mestrado). Escola de Comunicações e Artes, Programa de Pós-Graduação em Ciências da Comunicação, USP, São Paulo, 2001, 206p. 
COELHO, R. Da antropologia simbólica à antropologia cognitiva. Imaginário, n.1, p.11-39, 1993.

COELHO NETO, J.T. Semiótica, informação e comunicação. 4 a . ed., São Paulo: Editora Perspectiva, 1996, $220 \mathrm{p}$.

DONDIS, A. D. Sintaxe da linguagem visual. 3. ed., São Paulo: Martins Fontes, 2015, 235 p.

FIORI, S.R. Public Information symbols in Tourism: Importance, challenges, dimensions and empirical research. Revista Brasileira de Cartografia, n. 66/07, 2014, p. 1567-1586 (International Issues). Disponível em: <http://www.lsie.unb.br/rbc/index.php/rbc/article/ view/1717>. Acesso em 18 de ago. 2019.

Técnicas de desenho e elaboração de perfis. In: VENTURI, L.A.B. (Org.). Praticando Geografia: práticas de campo, laboratório e sala de aula. São Paulo: Editora Sarandi, 2011. p. 381 - 402, 2011.

Os Símbolos de Informação Pública nos setores do Lazer e do Turismo: resultados empíricos. Turismo em Análise, v. 21, n.2, 2010, p. 381-405. Disponível em: <https://doi.org/10.11606/issn.1984-4867.v21i2p381-405>. Acesso em 18 de ago. 2019. https://doi.org/10.11606/issn.1984-4867.v21i2p381-405

Mapas para o turismo e a interatividade: proposta teórica e prática. 2008. $310 \mathrm{f}$. Tese (Doutorado em Geografia Física) - Departamento de Geografia, Faculdade de Filosofia, Letras e Ciências Humanas, USP, São Paulo, 2008.

Mapas turísticos: o desafio do uso da arte na era digital. 2003. 204 f. Dissertação (Mestrado em Geografia Física) - Departamento de Geografia, Faculdade de Filosofia, Letras e Ciências Humanas, USP, São Paulo, 2003.

Atlas pictórico: proposta metodológica para elaboração e uso didático. 1999. 130 f. (Trabalho de Graduação Individual) - Departamento de Geografia, Faculdade de Filosofia, Letras e Ciências Humanas, USP, São Paulo, 1999.

FORREST, D. e CASTNER, H. W. The design and perception of point symbols for tourism maps. The Cartographic Journal, British Cartographic Society, London, vol. 22:11-29, jun. 1985. https://doi.org/10.1179/caj.1985.22.1.11

GERBER, R.; BURDEN, P. e STANTON, G. Development of Public Information Symbols for tourism and recreational mapping, The Cartographic Journal, British Cartographic Society, London, vol. 27: 92-103, dez. 1990. https://doi.org/10.1179/caj.1990.27.2.92

HALL, A. Fundamentos essenciais da ilustração. São Paulo: Rosari, 2012, 228 p.

KEATES, J. S. Understanding maps. New York: Longman, 1982, 140 p.

LUCENA, R.W.A. A ilustração no ensino de Geografia: proposta metodológica para elaboração e uso didático. 2018. 63 f. (Trabalho de Conclusão de Curso) - Deptartamento de Geografia, Instituto Multidisciplinar da Universidade Federal Rural do Rio de Janeiro, 2018.

MONEY, D.C. Basic Geography. 3a reimpr., New Zealand: University Tutorial Press Ltd, 1978, 160 p.

OLIVEIRA, D. Técnicas de Pedologia. In: VENTURI, L.A.B. (Org.). Praticando Geografia: práticas de campo, laboratório e sala de aula. São Paulo: Editora Sarandi, 2011. p. 83 - 106, 2011.

OLIVEIRA, L. Estudo metodológico e cognitivo do mapa. São Paulo: IGEOG-USP, 1977, 130p. (Série Teses e Monografias)

OXFORD UNIVERSITY PRESS. Atlas Geográfico Escolar Oxford. São Paulo: Oxford University Press, 2013, 160p.

PAIVA, J. Um estudo sobre a linguagem da ilustração e o design gráfico. In: BELUZZO, G. e SILVA, J. (Orgs.). Design, Arte, Moda e Tecnologia. São Paulo: Edições Rosari, 2010. p. 67 - 86. Disponível em: <https://docplayer.com.br/10481781-Design-arte-moda-e-tecnologia-organi zacaogisela-belluzzo-jofre-silva.html>. Acesso em: 05 ago. 2019.

PEIRCE, C.S. Semiótica. São Paulo: Editora Perspectiva, 2012, 340 p. 
ROCHA-TRINDADE, M. B. Imagens e aprendizagens na sociologia e na antropologia. In: FELDMANBIANCO, B. \& MOREIRA LEITE, M. L. Desafios da imagem: foto-grafia, iconografia e vídeo nas ciências sociais. Campinas: Papirus, p. 159-171, 1988.

SAMAIN, E. Questões heurísticas em torno do uso das imagens nas ciências sociais. In: FELDMANBIANCO, B. \& MOREIRA LEITE, M. L. Desafios da imagem: fotografia, Iconografia e vídeo nas ciências sociais. Campinas: Papirus, p.51-62, 1988.

SANTAELLA, L. O que é semiótica? 32ª reimpressão, São Paulo: Brasiliense, 2012, 132 p.

SILVA, N.; VALE , K. e FERREIRA, A. R. Arte na Geografia: um ensaio teórico-conceitual. São Luís: Clube de Autores, 2002, 84 p.

SIMIELLI, M. E. Geoatlas. 12.ed. São Paulo: Ática, 1993, 112p.

SIMÕES, J.F. Língua portuguesa aplicada à leitura e à produção de textos. Brasília: ATL, 2007, $260 \mathrm{p}$.

SOUZA, S. E. O uso de recursos didáticos no ensino escolar. In: I Encontro de Pesquisa em Educação, IV Jornada de práticas de Ensino, XIII Semana de Pedagogia da UEM: "Infância e práticas educativas. Maringá, 2007. Disponível em:<http://www.pec.uem.br/pec_ uem/revistas/arqmudi/volume_11/suplemento_02/artigos/019.pdf >. Acesso em: 5 abr. 2016.

SOUZA, S. R. M. Do conceito à imagem: fundamentos do design de pictogramas. 1992. $250 \mathrm{f}$. (Tese de doutorado) - Escola de Comunicações e Artes, Programa de Pós-Graduação em Ciências da Comunicação, USP, São Paulo, 1992.

SUETERGARAY, D. M. A. Terra: feições ilustradas. $3^{a}$ ed., Porto Alegre: Editora da UFRGS, 2008, 264p.

VASCONCELLOS, R. e ALVES FILHO, A.P. Novo Atlas geográfico ilustrado e comentado. São Paulo: FTD, 1999, 88 p.

VIGOTSKI, L.S. Formação social da mente. São Paulo: Martins Fontes, 1993, 191 p.

VIVOVERDE. A água que você não vê. Disponível em: < https://vivoverde.com.br/ diadaagua-aagua-que-voce-nao-ve/>. Acesso em 18 de ago. 2019.

XAVIER, G.C. Significante e significado no processo de alfabetização e letramento: contribuições de Saussure. Cadernos Cespuc, n. 25, p.87-102, 2014.

Recebido em: 27/09/2019

Aceito para publicação em: 20/03/2020 